\title{
The First Congress Canon and the Supreme Court's Use of History
}

\author{
Michael Bhargava $\dagger$
}

\section{INTRODUCTION}

In the 2003 case of Eldred $v$. Ashcroft, the Supreme Court employed a powerful yet problematic tool of constitutional interpretation: looking to the actions of the First Congress in resolving a modern-day legal dilemma. ${ }^{1}$ The Eldred Court decided whether Congress had the power to retroactively extend the period of copyright protection afforded to authors for previously published works. ${ }^{2}$ Eric Eldred, an Internet publisher of works in the public domain, argued that the 1998 Copyright Term Extension Act, which expanded the period of protection by twenty years, unconstitutionally violated his right to exploit works that were about to enter the public domain. ${ }^{3}$ The Court's response was straightforward: Congress had always lengthened existing copyright protection in this manner, beginning with the I790 Copyright Act passed by the First Congress. Because the First Congress had extended the period of copyright protection, the court reasoned that it must be constitutional today. ${ }^{4}$ The Court justified its ruling on a longstanding "principle that a contemporaneous legislative exposition of the Constitution when the founders of our Government and framers of our Constitution were actively participating in public affairs, acquiesced in for a long term of years, fixes the construction to be given [the Constitution's] provisions." If the First Congress believed that it had the power to extend copyrights, the Court concluded, then this settled the question. ${ }^{6}$ As Justice

Copyright 12006 California Law Review, Inc. California Law Review, Inc. (CLR) is a California nonprofit corporation. CLR and the authors are solely responsible for the content of their publications.

$\dagger \quad$ Associate, Winston \& Strawn LLP, Washington, D.C. J.D., School of Law, University of California, Berkeley (Boalt HaII), 2006; Ph.D., Duke University, 2000; A.B., Stanford University, 1992. The author would like to thank Philip Frickey, Pamela Samuelson, Jennifer Hcindl, Robert Boone, Rebecca Hart, and Alyson Tufts.

I. 537 U.S. $186(2003)$.

2. Id.

3. Id. at $\mathrm{I} 92$.

4. Id.

5. Id. at 2 I 3 (quoting Myers v. United States, 272 U.S. 52, I 75 (I926)).

6. Id. at 213 . 
Ruth Bader Ginsburg summarized for the Court, "a page of history is worth a volume of logic."7

By invoking the actions of the First Congress as dispositive, the Court curtly rejected an "elegantly complex, yet powerful"8 set of historical arguments by Mr. Eldred that sought to differentiate the actions of the First Congress from those of the modern Congress in extending the life of copyrights. Mr. Eldred argued that the 1790 Act did not extend existing copyrights, but rather created an entire system of copyright that displaced state protection and established a uniform federal standard. ${ }^{9}$ According to $\mathrm{Mr}$. Eldred, the 1790 Act stood "for nothing more than the need of the First Congress to address fundamental issues of transition from a state federation to a national government."10 As a result, the 1790 Act could not be compared with a modern act that arbitrarily extended all copyrights for twenty years. Nevertheless, the Court waved off the argument without addressing its merits, invoking the refrain that "Congress' unbroken practice since the founding generation thus overwhelms petitioners' argument. ..." But the Court, by conflating the 1790 copyright creation Act with the 1998 term extension Act, engaged in what one scholar has called "history a priori . . by judicial fiat." 12

The Eldred decision is only the most recent example of the Supreme Court's use of a method of constitutional interpretation that looks to the actions of the First Congress as weighty or even dispositive evidence of the meaning of the Constitution. The Court has sporadically trotted out this First Congress canon of constitutional interpretation in more than thirty decisions over the last 200 years. ${ }^{13}$ it has appeared in landmark decisions

7. Id. at 200 (quoting N.Y. Trust Co. v. Eisner, 256 U.S. 345, 349 (1921)).

8. Pamela Samuelson, The Constitutional Law of Intellectual Property After Eldred v. Ashcroft, 50 J. Copyright SOC'y 547, 555 (2003).

9. See Brief for the Petitioners at 28-30, Eldred v. Ashcroft, 537 U.S. 186 (2003) (No. 01-618). Interestingly, neither Eldred nor the Court questioned the legitimacy of looking to the First Congress as an arbiter of what was constitutional. Eldred simply argued that the First Congress' actions had a different purpose than those of the modern Congress, so the two could not be compared. On the propriety of looking to the actions of the First Congress, Eldred and the Court seemingly agreed.

10. Id. at 30 .

11. Eldred, 537 U.S. at 213-14.

12. Alfred H. Kelly, Clio and the Court: An Illicit Love Affair, 1965 Sup. CT. Rev. 119, 122 (1965) (internal quotations omitted). Professor Kelly defined this practice as "a simple declarative statement of a revelatory kind of what the original intent actually had been. As a rule this statement was allowed to stand without any supporting historical inquiry into the question at hand ..." $I d$. at 123 .

13. Although the Court has used this method of constitutional interpretation dozens of times, the method has never been formally labeled as a proper canon in the academic literature. However, the increasing frequency and importance of its use justifies this designation. 1 have called it the First Congress canon for the sake of simplicity, although the Court has occasionally wandered into the chambers of subsequent Congresses for constitutional enlightenment. This method of interpretation has been analyzed in passing in a small number of academic articles as "reliance on early legislative practice," "the use of custom," "contemporaneous exposition," or "reliance on tradition." See Note, Should the Supreme Court Presume that Congress Acts Constitutionally? The Role of the Canon of Avoidance and Reliance on Early Legislative Practice in Constitutional Interpretation, 116 HARv. L. 
such as Martin v. Hunter's Lessee, ${ }^{14}$ McCulloch v. Maryland,${ }^{15}$ and Scott $v$. Sandford. ${ }^{16}$ The Court has used the canon to address a wide range of issues including the sale of lottery tickets, ${ }^{17}$ the use of sampling in the U.S. census, ${ }^{18}$ the requirement for legislative chaplains, ${ }^{19}$ and the detention of prisoners of war. $^{20}$ Although the canon has at times merely supported a conclusion that the Court has made on other grounds, the Court has also, as in Eldred, invoked the actions of the First Congress as entirely dispositive.

The First Congress canon is a variant of the idea that long-standing tradition should not be disturbed. Justice Antonin Scalia, among others, has championed this canon, explaining that "when a practice not expressly prohibited by the text of the [Constitution] bears the endorsement of a long tradition of open, widespread, and unchallenged use that dates back to the beginning of the Republic, we have no proper basis for striking it down."21 The First Congress canon looks specifically at a legislature graced with the presence of Framers, who, it is asserted, provide unique insights into the Constitution. ${ }^{22}$ Even the non-Framers in the First Congress have special status under the canon, as contemporaries of the Constitution. ${ }^{23}$

Despite the Court's occasional use of the canon, however, it has never fully explained why the actions of the First Congress should carry such great weight in its constitutional interpretation. The Court's use of the First Congress canon poses a number of interpretative difficulties that cannot easily be resolved by casual references to its proximity to, and overlap

REv. 1798, 1809 (2003); Michael J. Glennon, The Use of Custom in Resolving Separation of Powers Disputes, 64 B.U. L. REV. 109 (1984); Rebecca L. Brown, Essay: Tradition and Insight, 103 YALE L.J. 177 (1993). See also Jason T. Bumette, Eyes on their Own Paper: Practical Construction in Constitutional Interpretation, 39 GA. L. REv. 1065 (2005), which focuses on the overlapping concept of "practical construction," in which the judiciary gives a presumption of constitutionality to the ways in which the executive and legislative branches conduct their affairs. However, no article has focused on the First Congress canon as an interpretive tool in itself.

14. 14 U.S. 304 (1816).

15. 17 U.S. $316(1819)$.

16. 60 U.S. 393 (1857).

17. Cohens v. Virginia, 19 U.S. 264 (1821).

18. Utah v. Evans, 536 U.S. 452 (2002).

19. Marsh v. Chambers, 463 U.S. 783 (1983).

20. Ex parte Quirin, 317 U.S. 1 (1942).

21. Rutan v. Republican Party of 111., 497 U.S. 62, 95-96 (1990) (Scalia, J., dissenting).

22. According to Chief Justice William Howard Taft, the actions of the First Congress feature: [A] construction of the Constitution made by a Congress which was to provide by legislation for the organization of the Government in accord with the Constitution which had just then been adopted, and in which there were, as representatives and senators, a considerable number of those who had been members of the Convention that framed the Constitution and presented it for ratification.

Myers v. United States, 272 U.S. 52, 174 (1926).

23. See, e.g., Burrow-Giles Lithographic Co. v. Sarony, 111 U.S. 53, 57 (1884) ("The construction placed upon the Constitution by the first act of 1790 , and the act of 1802 , by the men who were contemporary with its formation, many of whom were members of the convention which framed it, is of itself entitled to very great weight, and when it is remembered that the rights thus established have not been disputed during a period of nearly a century, it is almost conclusive."). 
with, the Founding Fathers. Most notably, delving into the history of the First Congress raises questions as to the capacity of any court fully to understand the historical context of a distant period, a problem that one scholar has referred to as "law-office history." ${ }^{24}$ For instance, the First Congress canon raises a range of theoretical issues challenging whether the actions of the first legislature can be used to divine the original intent or understanding of the founders. Further, it raises more practical issues about the proper use (and potential misuse) of those insights in deciding modernday constitutional dilemmas. The Supreme Court has never grappled with these issues, at least publicly, and yet it continues to invoke the actions of the First Congress almost as the received word of the founders.

Despite the relative frequency of the Supreme Court's use of the First Congress canon, it rests on rather fragile historical foundations. Part I traces the history of the Court's use of the canon, beginning in 1803 with Stuart v. Laird, ${ }^{25}$ in which the Court invented the canon as a means of avoiding a prickly political dilemma. The canon can be broken down into two key parts. First, the Supreme Court examines the actions of the First Congress to ascertain either the original intent of the Framers of the Constitution or the original understanding of the Constitution by the founding generation. Part II examines whether the Court truly succeeds at this task and whether such a goal is realistic. Second, to sufficiently fix the meaning of the Constitution, the co-equal branches of government must be seen to have acquiesced to the First Congress' actions. Part III analyzes the problem of finding acquiescence and suggests why apparent submission to the will of the First Congress may not be a reliable basis for constitutional interpretation.

\section{I}

\section{History of THE First CONGRESS CANON}

The Supreme Court has invoked the First Congress canon more than thirty times, beginning with the 1803 case of Stuart v. Laird and extending to Eldred v. Ashcroft exactly two centuries later. Its use has come in fits and spurts, with concentrations of use in the $1880 \mathrm{~s}$, the 1920s, and in the modern era of renewed interest in originalism. At other times, the Court hardly invoked the canon, with only a single use between 1901 and 1926, and not a single use in the 1950s or 1960s. Furthermore, the Court has employed the canon in only limited contexts, with multiple decisions in the

24. Kelly, supra note 12 , at 122 n.13 (internal quotations omitted). Kelly defined law-office history as "the selection of data favorable to the position being advanced without regard to or concem for contradictory data or proper evaluation of the relevance of thc data proffered." Id. Justice Scalia has noted the difficulty of judges properly interpreting history, calling it one of the warts on the face of originalist theory. See Antonin Scalia, Originalism: The Lesser Evil, 57 U. CIN. L. Rev. 849, 856-57 (1989).

25. 5 U.S. 299 (1803). 
same area, as if the Court had been reminded of the canon when it reviewed its own precedents. The canon has been a repeat player in decisions addressing the Court's jurisdiction (four times), copyright (two times), delegation of power to the executive (six times), taxation (three times), the Establishment Clause (two times), and the limits of congressional power (eight times).

\section{$A$. Stuart v. Laird (1803) and the Origins of the First Congress Canon}

The Supreme Court first invented the First Congress canon in 1803 in Stuart $v$. Laird. ${ }^{26}$ The case arose from the partisan battles between the Federalist Party and the newly empowered Republicans, led by Thomas Jefferson. In 1801, the Federalists, having lost the presidency and Congress in the 1800 elections, sought to stem their losses by solidifying their control over the federal judiciary. The lame-duck Federalist Congress passed the Judiciary Act of 1801, which reorganized the federal courts and created sixteen new circuit judgeships that the Federalists could fill before Jefferson assumed the presidency in March 1801. ${ }^{27}$ Squabbles over filling those "midnight appointments" resulted in the landmark Marbury $v$. Madison decision, which was issued six days before Stuart v. Laird. ${ }^{28}$ The 1801 Act also ended the practice of circuit riding that the 1789 Judiciary Act had established, under which Supreme Court Justices undertook arduous semi-annual tours of their assigned circuits in order to preside over court business across the United States.

The incoming Congress, dominated by Republicans, promptly repealed the 1801 court reorganization with its own Judiciary Act of $1802 .{ }^{29}$ That Act abolished the new circuit system, reinstated the practice of circuit riding, and transferred all cases pending within the new circuits to the courts in which they would have been filed under the 1789 system. $^{30}$ Caught in the middle of this back-and-forth was John Laird, a British subject who had won a judgment against Hugh Stuart of Virginia in the Fourth Circuit under the 1801 Act. After Stuart failed to comply with the judgment, Laird returned to court in 1802 to enforce it. By this time, however, the original court no longer existed, and his case was transferred to a new court. Stuart challenged the jurisdiction of the new court, arguing that the

26. Id.

27. Act to Provide for the More Convenient Organization of the Courts of the United States, ch. 4, 2 Stat. 89 (1801) (repealed 1802). The Act created six new circuits, the first five of which would have three new judges. The Sixth Circuit would consist of a single circuit court judge and the district judges of Kentucky and Tennessee. $I d$. at $\S \S 6-7$. Under the Judiciary Act of 1789 , the three circuits had previously consisted of two Supreme Court justices riding circuit, as well as a district court judge. See An Act to Establish the Judicial Courts of the United States, ch. 20, 1 Stat. 73 (1789).

28. Marbury v. Madison, 5 U.S. 137 (1803).

29. Act to Repeal Certain Acts Respecting the Organization of the Courts of the United States, ch. 8,2 Stat $132(1802)$.

30. Id. $\$ 4$. 
judgment could be enforced only in the court in which it had been originally decided. Chief Justice John Marshall, deciding the case at the circuit court level, rejected Stuart's argument, and the decision was appealed to the Supreme Court.

Federalist Charles Lee, former Attorney General for Presidents Washington and Adams, represented Laird before the Supreme Court. Lee argued that the 1802 Repeal Act was unconstitutional. First, the Act deprived the newly appointed circuit judges of their positions, contrary to the constitutional requirement that judges be appointed for life. ${ }^{31}$ Second, by resurrecting circuit riding and forcing Supreme Court Justices to also serve as circuit court judges, Congress had in essence appointed them to new positions, despite the constitutional requirement that the President appoint judges with the advice and consent of the Senate. ${ }^{32}$ In addition, circuit riding forced Justices to preside over cases of original jurisdiction in the circuit courts, and then to hear the same cases in an appellate capacity at the Supreme Court. ${ }^{33}$ As a result, the Justices would hear cases of original jurisdiction beyond what the Constitution allowed. ${ }^{34}$ Lee explained to the Court that " $[\mathrm{t}] \mathrm{he}$ jurisdiction of the supreme court, therefore, being appellate only, no judge of that court, as such, [is] authorized to hold a court of original jurisdiction." "35 This second claim was the weaker of the two, since it required a conflation of the limitations on the Supreme Court and those on its individual Justices. However, if the Court were to hold that the Justices were distinct from the Court, it would only serve to strengthen the first argument that a separate appointment was required for the circuit court position.

Stuart countered Laird's arguments of unconstitutionality with an appeal to customary practice: Supreme Court Justices rode circuit since the founding, and they should continue to do so.

[I]t is most probable that the members of the first congress, many of them having been members of the convention which formed the constitution, best knew its meaning and true construction. But if they were mistaken, yet the acquiescence of the judges and of the people under that construction, has given it a sanction which ought not now to be questioned. ${ }^{36}$

Charles Lee countered, "An error was committed in 1789. That act was unconstitutional, but the act of 1801 restored the system to its

31. U.S. ConsT. art. III, $\$ 1$.

32. $\quad I d$. at art. II, $\S 2$.

33. The Circuit Courts in the early Republic were primarily trial courts rather than the appeals courts that they later became. See Charles Alan Wright \& Mary Kay Kane, Law of Federal Courts $4\left(6^{\text {th }}\right.$ ed. 2002$)$.

34. U.S. ConsT. art. III, § 2.

35. Stuart v. Laird, 5 U.S. 299, 305 (1803) (emphasis omitted).

36. Id. at 307-08. 
constitutional limits. We now contend for the pure construction of the constitution, and hope it will be established, notwithstanding the precedent to the contrary." 37

Despite the weighty constitutional issues, and despite the personal interests of the Justices in having to ride circuit, the Court affirmed the 1802 repeal Act in a brief four-paragraph decision. The unanimous opinion by four Justices-excluding Chief Justice Marshall, who recused himself after hearing the case at the circuit level, and Justice William Cushing, who absented himself because of poor health-failed to tackle any of the constitutional issues. Justice William Paterson's opinion held that Congress had the power to establish inferior tribunals, saying nothing about the constitutional objection that it would in the process deprive sitting judges of their seats. On the issue of circuit riding, the Court concluded its opinion with the First Congress canon,

To this objection, which is of recent date, it is sufficient to observe, that practice and acquiescence under it for a period of several years, commencing with the organization of the judicial system, affords an irresistible answer, and has indeed fixed the construction. It is a contemporary interpretation of the most forcible nature. This practical exposition is too strong and obstinate to be shaken or controlled. Of course, the question is a[t] rest, and ought not now to be disturbed. ${ }^{38}$

The decision touched none of the constitutional issues and only weakly concluded that past practice should prevail. Parroting Stuart's argument, the Court deferred to the wisdom of the First Congress, which fixed the meaning of the Constitution based on its own proximity to the document's creation. When faced with a clear constitutional question, one that could have relieved the Justices of their despised circuit-riding duties, the Court dodged the issue.

The Court's reasoning is at best incomplete, and at worst disingenuous. The opinion does not remotely do justice to concerns over the practice of circuit riding. Faced with a serious constitutional issue, the Court deferred to the wisdom of Congress, presumably assuming that it knew best. The result is especially surprising because the Justices had two very compelling reasons to rule against the practice.

First, circuit riding was by far the most onerous and hated of their responsibilities. Twice a year, the Justices left the Court to travel to the far reaches of the country, traversing difficult roads and suffering from meager accommodations. ${ }^{39}$ Supreme Court Justices had vigorously complained

\footnotetext{
37. Id. at 308 .

38. Id. at 309 .

39. See generally Wythe Holt, "The Federal Courts Have Enemies in All Who Fear Their Influence on State Objects": The Failure to Abolish Supreme Court Circuit-Riding in the Judiciary Acts of I792 and 1793, 36 BufF. L. Rev. 301 (1987).
} 
about circuit riding since it was instituted in 1789, belying Paterson's assertion in Stuart that the objection was "of recent date." In particular, the Southern Circuit, which was far from the Supreme Court's seat in New York, caused particular hardship on the Justices. ${ }^{40}$ Justice James 1redell, who rode the Southern Circuit, likened himself to a "travelling postboy."41 The aging Justice Cushing complained to Justice Paterson that he "had been obliged ... to be absent from home in my last Excursion on Judicial duty, above fourteen months, save only four weeks." ${ }^{24}$ In 1792, the entire Supreme Court signed a letter to the Congress complaining of the circuitriding duties:

[S]ome of the present Judges do not enjoy health and strength of body sufficient to enable them to undergo the toilsome Journies... nor is it probable that any set of Judges however robust, would be able to support... such severe duties for any length of time. ${ }^{43}$

Second, despite Paterson's claim, the Justices never acquiesced to the constitutionality of circuit riding, but had consistently expressed their concerns almost since the 1789 Judiciary Act first took effect. In August 1790, Justice John Blair wrote to Chief Justice John Jay that "the circuit system may not be perfectly consistent with the spirit of the Constitution, which intended the supreme court as a dernier resort only ...."44 $\mathrm{He}$ explained that it was "liable to objection, that men who have decided a cause in one court, should determine it again in an appellative capacity." "the constitution seems also to have intended, that the judges of such inferior courts as Congress might see fit to establish should be a sett [sic] of judges distinct from those of the supreme court . . .",46

Various Justices also expressed their concern over the constitutionality of circuit riding even in the days before deciding Stuart. Relieved to be

40. See Charles Warren, 1 The Supreme Court In Unted States History 86 (1922). The Court began meeting in Philadelphia during its third term. Id. at 53.

41. Id. at 86 .

42. Letter from William Cushing to William Paterson (Mar. 5, 1793), quoted in Holt, supra note 39 , at 309 .

43. Letter from the Justices of the Supreme Court to the Congress of the United States (Aug. 9, 1792), in 2 Documentary History of the Supreme Court, i789-1800 290 (Maeva Marcus ed., 1988) [hereinafter 2 DHSC].

44. Letter from John Blair to John Jay (Aug. 5, 1790), in 2 DHSC, supra note 43, at 84.

45. Id.

46. Id. (emphasis in original). John Jay similarly believed Congress' circuit-riding system to be unconstitutional. In September 1790, he drafted a letter to be sent on behalf of all the justices to President Washington outlining their objections to circuit riding. He first excused Congress' lapse into unconstitutionality: "It would doubtless have been singular, if a System so new and untried, and which was necessarily formed more on Principles of Theory and probable Expediency, than former Experience, had, in Practice, been found entirely free from Defects." Nevertheless, he eontinued, "[o]n comparing this Act with the Constitution, we perceive Deviations ...." Jay then identified the same constitutional problems with the circuit-riding system that Stuart $v$. Laird would raise thirteen years later. See Justices of the Supreme Court to George Washington, Sept. 13, 1790, in id. at 89. 
done with riding circuit after the 1801 Judiciary Act ended, the threat that it would be revived by a Republican Congress alarmed the Justices, resulting in a flurry of letters among them in 1802. At first, Chief Justice Marshall took the position that the Court eventually adopted in Stuart v. Laird. In a letter to Justice Paterson, he wrote, "I confess I have some strong constitutional scruples" over the 1802 repeal act." "If the question was new I should be unwilling to act in this character [by continuing to ride circuit] without a consultation of the Judges; but I consider it as decided \& that whatever my own scruples may be I am bound by the decision [of Congress].".48

As he came to consider the question, however, he became increasingly convinced that circuit riding violated the Constitution. He wrote to Justice Cushing that "I more than doubt the constitutionality of this measure \& of performing circuit duty without a commission as a circuit Judge." ${ }^{\prime 49}$ However, in soliciting Justice Cushing's opinion, he indicated that "I shall hold myself bound by the opinions of my brothers." "50 Justice Samuel Chase was most forceful in expressing his belief that circuit riding violated the Constitution. In a letter to Chief Justice Marshall, he wrote that the 1802 Repeal Act clearly violated the Constitution by denymg sitting circuit judges of their current seats. "It is a great doubt with me, whether the Circuit Courts, established by the Law, can be abolished; but I have no doubt, that the Circuit Judges cannot, directly, or indirectly, be deprived of their Offices, or Commissions, or Salaries, during their lives." 52

In his survey of the Justices, however, Chief Justice Marshall met resistance to the idea of overturning the practice of circuit riding. According to Marshall, Justice Bushrod Washington believed that "the question respecting the constitutional right of the Judges of the supreme court to sit as circuit Judges ought to be considered as settled \& shoud [sic] not again be movd [sic]." 53 Justice Paterson agreed. He wrote to Cushing that "my opin[i]on coincides with Justice Washington's. Practic[e] has fixed the construction, which it is too late to disturb. If open for discussion, it would merit serious consideration; but the practical exposition is too old and

47. Letter from John Marshall to William Paterson (Apr. 6, 1802), in 6 The PAPERS OF JoHN Marshall 106 (Charles F. Hobson ed., 2000) [hereinafter MarShall PaPers].

48. Id.

49. Letter from John Marshall to William Cushing (Apr. 19, 1802), in Marshall PaPers, supra note 47 , at 108

50. Id.

51. Letter from Samuel Chase to John Marshall (Apr. 24, 1802), in Marshall PaPers, supra note 47 , at 110

52. Id. (emphasis in original).

53. Letter from John Marshall to William Paterson (May 3, 1802), in MARShall PAPERS, supra note 47 , at 117 . 
strong \& obstinate to be shaken or controlled. The question is at rest." 54 Justice Cushing agreed that "if the point had been started at first, I believe doubts would have arisen. But as the case is-to be consistent I think we must abide by the old practice."

In the end, Marshall conceded the point. In a letter to Paterson, he wrote, "I have no doubt myself but that policy dictates this decision to us all. I own I shall be privately gratified if such shoud [sic] be the opinion of the majority \& I shall with much pleasure acquiesce in it ..."56 When he confronted the case of Stuart $v$. Laird while sitting on the Fifth Circuit in December 1802, Marshall dismissed the defendant's constitutional arguments, setting the stage for the Supreme Court to rule.

The 1802 correspondence among the Justices raises a number of questions. Justices Chase and Marshall both believed circuit riding to be unconstitutional, but Justices Paterson, Washington, and Cushing believed the question had been settled by the Court's acquiescence in the past. ${ }^{57}$ However, Justices Paterson and Cushing indicated that had the question arisen earlier, the Court might have determined that circuit riding violated the Constitution. Neither explains, either in the Stuart decision or in their letters, why a span of only twelve years between first riding circuit in 1790 and their 1802 discussion should have settled the question in favor of constitutionality.

The likely answer is that the Justices were politically savvy and knew better than to take on Congress over the 1802 Act. The first years of the nineteenth century were politically bruising, particularly for the Federalists, who still dominated the federal judiciary. The Republican Congress had already declared war on the last remaining Federalist stronghold in government by passing the 1802 Act, which deprived sixteen Federalist circuit court judges of their jobs. ${ }^{58}$ As one writer explained, in the faee of extreme

54. Letter from Hannah Cushing to Abigail Adams (June 25, 1802), in Marshall. PaPERS, supra note 47 , at $118 \mathrm{n} .6$.

55. Quoted in letter from William Paterson to John Marshall (June 11, 1802), in MARSHALL PAPERS, supra note 47 , at 120.

56. Letter from John Marshall to William Paterson (May 3, 1802), in MARSHALL. PAPERS, supra note 47 at 117 .

57. The views of the final Justice, Alfred Moore, are unknown, but he did not dissent to the unanimous opinion in Stuart v. Laird.

58. According to Republican Senator William Branch Giles, "What concerns us most is the situation of the Judiciary as now organized. It is constantly asserted that the Revolution is incomplete, as long as that strong fortress is in possession of the enemy... No remedy is competent to redress the evil system but an absolute repeal of the whole Judiciary [Act of 1801] and terminating the present offices and creating a new system." Letter from William Branch Giles to Thomas Jefferson (June 1801), cited in Richard E. Ellis, The Jeffersonian Crisis 20-21 (1971). The Republican Congress' battle against the Federalists did not stop with the Judiciary Act. The Congress also passed a bill that adjourned the Supreme Court until February 1803, specifically ensuring that the Court could not review the 1802 repeal Act before it beeame law. See id. at 59. Marshall lamented the loss of the June 1802 term, writing that "1 coud [sic] have wishd [sic] the Judges had convend [sic] before [Congrcss] proceeded to execute the new system." John Marshall, To William Paterson, in Marshall Papers, 
pressure from Jeffersonians, the Justices acted "primarily out of fear for their own reputations, and fear of the ravages of open warfare, perhaps entailing bloodshed. They got cold feet, as humans often do." 59

Perhaps the ultimate irony of the Stuart case is that Justice Paterson, who wrote the decision deferring to the wisdom of the First Congress, was himself a member of that Congress. Paterson was also a delegate to the Constitutional Convention in 1787 and a signer of the Constitution. After being elected to the Senate seat from New Jersey in 1788, Paterson served until November 1790, when he was elected Governor of New Jersey. ${ }^{60}$ By 1803, therefore, Paterson had helped frame the Constitution, had voted to pass the 1789 Judiciary Act-at least one of whose provisions was unconstitutional-and then had struck down that very provision in Marbury as unconstitutional. Six days later, he authored an opinion indicating that circuit riding could not be unconstitutional because a 1789 act of First Congress was a "contemporary interpretation of the most forcible nature ... too strong and obstinate to be shaken or controlled."

\section{B. The Canonization of the Canon: Use of the Canon from 1803-1842}

Stuart represented the Court's tactical retreat from the partisan politics of the time. By deferring to the wisdom of the First Congress in establishing the circuit-riding system, and by accepting twelve years of practice as sufficient to fix constitutional meaning, the Court extricated itself from a politically awkward situation. True to the canon's roots, the Court has continued to use the canon as an instrument of expediency in resolving difficult issues.

The Supreme Court further developed what would become the First Congress canon in the landmark 1816 case of Martin $v$. Hunter's Lessee, in which the ownership of a disputed piece of land depended on whether a treaty trumped state law. ${ }^{62}$ More importantly, the case examined whether the constitutional decisions of the Supreme Court bound state courts. After explaining the constitutional basis of the supremacy of Supreme Court

supra note 47 , at 106 . The Congress also wielded its power of impeachment against Federalist judges. In 1804, Congress impeached and convicted New Hampshire distriet court Judge John Pickering, who had beeome mentally ill while on the bench. They did so by charging him not with insanity, but with being a drunkard, which they defined as a "high crime and misdemeanor" worthy of removal from office. See Garry Wills, "Negro President": Jefferson and the Slave Power 140-43 (2003). In 1805, the House of Representatives impeached Supreme Court Justice Samuel Chase for the audacity of convicting people under the Alien and Sedition Act, when that was the law of the land. Id. at 143-46. Although the Senate voted not to convict Chase, the trial represented the depth of the partisan acrimony that plagued the country during the Jeffersonian era.

59. Wythe Holt \& David A. Nourse, Egbert Benson: First Chief Justice of the Second CirCuit (1801-1802) 15 (1987).

60. See William R. Casto, The Supreme Court in the Early Republic 64-65 (1995).

61. Stuart v. Laird, 5 U.S. 299,308 (1803).

62. Martin v. Hunter's Lessee, 14 U.S. 304, 351-52 (1816). 
judgments, the Court cited the same conclusion found in the 1789 Judiciary Act, which was "submitted to the deliberations of the first congress, composed, as it was ... of men who had acted a principal part in framing, supporting, or opposing that constitution, [and] the same exposition was explicitly declared and admitted by the friends and by the opponents of that system." ${ }^{33}$ The fact that the First Congress gave the Supreme Court appellate jurisdiction over state courts, combined with the acquiescence since 1789 of that power, "place[s] the doctrine upon a foundation of authority which cannot be shaken, without delivering over the subject to perpetual and irremediable doubts." ${ }^{64}$ Unlike in Stuart, however, the invocation of the wisdom the First Congress was not a determinative argument, but merely a confirmation of what the Constitution itself declared.

The doctrine next made an appearance--likely its most famous - in McCulloch v. Maryland ${ }^{65}$ Challenged by an obstreperous Maryland legislature intent on taxing it, the Bank of the United States found refuge in the Supreme Court, which dismissed the notion that the First Congress exceeded its powers in creating the Bank. "This can scarcely be considered as an open question," scoffed the Court. ${ }^{66}$ After all, this question was resolved in Congress' favor "at a very early period of our history" and had been subsequently ratified by the acquiescence of all branches of government. ${ }^{67}$ "An exposition of the constitution, deliberately established by legislative acts, on the faith of which an immense property has been advanced, ought not to be lightly disregarded." ${ }^{\prime 68}$ Furthermore, the original bank bill in 1789 "did not steal upon an unsuspecting legislature, and pass unobserved" but was measured "first in the fair and open field of debate ... and being supported by arguments which convinced minds as pure and as intelligent as this country can boast, it became a law." ${ }^{99}$ Under such circumstances, it would "require no ordinary share of intrepidity" to assert that the Bank's establishment was unconstitutional. ${ }^{70}$

A canon becomes a canon once courts cite it as if it were one. By that standard, the reasoning in Stuart became canonized in 1842, when Justice Story cited Stuart in overturning a Pennsylvania law aimed at preventing the return of fugitive slaves in Prigg v. Pennsylvania. ${ }^{71}$ The statute at issue in Prigg forbade the forcible return of escaped slaves, despite the constitutional provision that any "person held to service or labour in one

\footnotetext{
63. Id. at 351 .

64. Id. at 352 .

65. 17 U.S. 316 (1819).

66. Id. at 400 .

67. Id.

68. Id.

69. Id. at 402 .

70. Id.

71. 41 U.S. 539 (1842)
} 
state ... shall be delivered up on claim of the party to whom such service or labour may be due." ${ }^{72}$ In I793, Congress passed a fugitive slave law enforcing this provision, but Pennsylvania argued that Congress exceeded its authority because the law was not within an enumerated power of the Constitution. Justice Joseph Story, writing for a unanimous Court, dismissed this argument, holding that "where the end is required [by the Constitution], the means are given." 73 Furthermore, the Court may "rely upon contemporaneous expositions of the Constitution, and long acquiescence in it, with great confidence, in the discussion of questions of a highly interesting and important nature."74 The Court, however, used the First Congress canon modestly, emphasizing that it was by no means dispositive, but merely supported the opinion of the Court:

[W] do not wish to rest our present opinion upon the ground either of contemporaneous exposition, or long acquiescence, or cven practical action; neither do we mean to admit the question to be of a doubtful nature, and therefore as properly calling for the aid of such considerations. On the contrary, our judgment would be the same if the question were entirely new, and the act of Congress were of recent enactment. We hold the act to be clearly constitutional in all its leading provisions. ${ }^{75}$

Story cited Stuart hcre as giving only a modicum of weight to the contemporaneous exposition of the Constitution by the First Congress. Such judicious use of the canon, however, would not always be applied by future Courts, some of which found the actions of the First Congress to be absolutely dispositive even in the face of historical ambiguity.

\section{The First Congress Canon and Original Intent: The Canon from 1842 to the Present}

The continuing history of the canon imperfectly maps debates over originalism, with which the canon is necessarily linked. It also mirrors the Court's use of history as a guide in constitutional decision making. The Court cited the canon in fits and spurts during the nineteenth and twentieth centuries, partly in response to prevailing ideas about the importance of original intent. The idea that the Constitution should be interpreted according to the original intent of the Framers dominated the legal landscape in the nineteenth century. Before the rise of the idea of a "living Constitution" in the twentieth century, "constitutional interpretation was understood as the ascertainment and application of the fixed, unchanging meaning of the

72. U.S. Const, art. IV, $\$ 2$.

73. Prigg, 4I U.S. at 615.

74. Id. at 621 .

75. Id. at $62 \mathrm{I}-22$. 
written Constitution." "76 Chief Justice Roger Taney perhaps put it best, explaining in the Dred Scott decision that "as long as [the Constitution] continues to exist in its present form, it speaks not only in the same words, but with the same meaning and intent with which it spoke when it came from the hands of its [F]ramers." 77

However, nineteenth-century originalism was largely based on the text of the Constitution rather than on extrinsic evidence from ratification debates or the Constitutional Convention's secret history. ${ }^{78}$ The First Congress canon teamed the notion of original intent with that of contemporary exposition, first expounded in Lord Coke's axiom, "Contemporanea espositio est fortissimo in lege": An interpretation of a text-whether legislative or constitutional-receives greater weight when it occurs concurrently with its adoption. ${ }^{79}$ James Madison appeared to support the use of contemporary practice to divine the intent of the Constitution. He wrote that in interpreting the Constitution, "the intention of the parties to it ought to be kept in view; and that as far as the language of the instrument will permit, this intention ought to be traced in the contemporaneous exposition." 80 As Representative William Vans Murray explained in 1796, "We have all seen the Constitution from its craddle [sic], we know it from its infancy and have the most perfect knowledge of it, and more light than ever a body of men in any country ever had of ascertaining any other Constitution." 81

Although the plain meaning of the Constitution always trumps historical evidence, such evidence can be consulted to interpret nuances of constitutional text. Justice Joseph Story, in his Commentaries on the Constitution of the United States, wrote that

[c]ontemporary construction is properly resorted to, to illustrate, and confirm the text, to explain a doubtful phrase, or to expound an obscure clause; and in proportion to the uniformity and universality of that construction, and the known ability and talents of those, by whom it is given, is the credit, to which it is entitled. ${ }^{82}$

76. Jonathan O'Neill, Originalism in American law and Politics: A Constitutional HisTORY 12 (2005).

77. See Scott v. Sandford, 60 U.S. 393, 426 (1957). Unfortunately, although he professed originalism, Chief Justice Taney badly distorted the historical record in reading African Americans out of the Constitution entirely. See the dissenting opinion of Justice Curtis for an alternative version of that history. Id at 564 (Curtis, J., dissenting).

78. See O'NeILL, supra note 76, at 12-13.

79. Lord Edward Coke, 1 The Second Part of the Institutes of the Laws of England 10 (1809).

80. Letter from James Madison to Spencer Roane, in 9 WRITINGS of James Madison 59 (Gaillard Hunt cd., 1910).

81. See 5 The Debates and Proceedings in the Congress of the United States 701 (Gales \& Seaton eds., 1834) [hereinafter ANNALS OF Congress].

82. Joseph Story, Commentaries on the Constitution of the United States 390 (1833). 
Under this standard, members of the First Congress, who in Justice Marshall's words had "minds as pure and as intelligent as this country can boast,"83 clearly deserved extraordinary weight.

The notion of the living Constitution emerged from the Civil War in reaction to the devastation that the compromises sown in 1787 over slavery reaped in the $1860 \mathrm{~s}^{84}$ Even so, the Supreme Court adhered to an originalist notion of the Constitution, refusing to countenance the idea that the document could change with the times. ${ }^{85}$ Following its apparent newfound devotion to original intent, the Court seemingly rediscovered the First Congress canon in the $1880 \mathrm{~s}$, using it at least eleven different times between 1883 and $1901 .^{86}$ The Court used the canon to examine the constitutionality of legislation on the eligibility of photographs for copyright protection, ${ }^{87}$ the manner in which a state chose its presidential electors, ${ }^{88}$ estate taxes, ${ }^{89}$ and the delegation of legislative power to the President. ${ }^{90}$ The Court employed the canon modestly in a few cases. In McPherson $v$. Blacker, for example, the Court examined a Michigan statute that allowed local districts to choose their presidential electors. ${ }^{91}$ Chief Justice Fuller, writing for a unanimous majority, held that this practice did not violate the constitutional requirement that electors be chosen by the state legislatures. The Court carefully explained that contemporaneous practice became relevant only "where there is ambiguity or doubt, or where two views may well be entertained" about the construction of constitutional text. ${ }^{92}$ Finding some ambiguity after a lengthy examination of the text, the Court looked at state and federal practices shortly after the Constitution to show that a number of states chose their electors by district and that the Congress did

83. McCulloch v. Maryland, 17 U.S. 316, 401-02 (1819).

84. Barry Friedman \& Scott B. Smith, The Sedimentary Constitution, 147 U. PA. L. Rev. 1, 14 (1998).

85. See, e.g., Hepburn v. Griswold, 75 U.S. 603, 625 (1870).

86. The Court's use of the canon had waned in the forty years aftcr Prigg, with only two recorded uses in the 1850s. See Cooley v. Bd. of Wardens, 53 U.S. 299, 315 (1852); Scott v. Sandford, 60 U.S. 393,616 (1857). In Cooley, the canon was vital to the Court's determination of the question. See infra Part III. In the Dred Scott case, the dissent mentioned the canon only in passing. But the canon received significantly more use from the Court beginning in the 1880s. See Downes v. Bidwell, 182 U.S. 244, 286 (1901); Fairbank v. United States, 181 U.S. 283, 311-12 (1901); Knowlton v. Moore, 178 U.S. 41, $56-57$ (1900); Sparf v. United States, 156 U.S. 51, 169 (1895) (Gray, J., dissenting); McPherson v. Blacker, 146 U.S. 1, 27 (1892); Marshall Field \& Co. v. Clark, 143 U.S. 649, 690-91 (1892); Wisconsin v. Pelican lns. Co., 127 U.S. 265, 297 (1888); The Laura, 114 U.S. 411, 416 (1885); Cooper Mfg. Co. v. Fcrguson, 113 U.S. 727, 732 (1885) (applying the doctrine to the Colorado state constitution); Ames v. Kansas, 111 U.S. 449, 469 (1884); Burrow-Giles Lithographic Co. v. Sarony, 111 U.S. 53, 57 (1884).

87. Burrow-Giles Lithographic Co., 111 U.S. at 57.

88. McPherson, 146 U.S. at 27.

89. Knowlton, 178 U.S. at 56-57.

90. Marshall Field \& Co., 143 U.S. at $690-91$.

91. McPherson, 146 U.S. at 1.

92. Id. at 27 
not object. Evidence of such practice is "entitled to the greatest weight" because of the paucity of evidence from the constitutional text. ${ }^{93}$

The Court, however, did not always apply the canon with such skill. In Burrow-Giles Lithographic Company v. Sarony, the Court faced the question of whether a photograph-in this case, one of Oscar Wildecould receive copyright protection despite the constitutional provision that copyright should apply to "writings." 94 In deciding the question, the Court never conducted a textual analysis of the Copyright Clause. Instead, it merely looked at the 1790 Copyright Act, which extended protection to maps and charts, ${ }^{95}$ as well as the 1802 Copyright Act, which broadened the protection to designs, engravings, and etchings of prints. ${ }^{96}$ The Court found both acts to be contemporaneous explications of the Constitution, and thereby "entitled to very great weight." 97 The Court concluded that "when it is remembered that the rights thus established have not been disputed during a period of nearly a century, it is almost conclusive." the First Congress canon, the Court never answered the question in front of it, whether a photograph could constitute a "writing."

\section{The First Congress Canon Waivers in the $20^{\text {th }}$ Century}

The canon took a hiatus for the first quarter of the twentieth century, in which the Court cited it only once. ${ }^{99}$ This period coincided with a period in which the Court rarely turned to history as a guide for its decisions. ${ }^{100}$ The Court resurrected the First Congress canon in 1926 and used it five times between that year and $1942 .^{101}$ The most important use came in the case of Myers $v$. United States. ${ }^{102}$ Chief Justice William Howard Taft, who wrote for the majority, later explained, "1 never wrote an opinion that 1 felt to be so important in its effect." 103 Perhaps reflecting his former experience as President of the United States, Taft upheld the President's right to remove executive officers at his discretion. He relied in part on a decision made by the First Congress to remove language from a bill creating a Department of Foreign Affairs that allowed officers "to be removable from

93. Id.

94. 111 U.S. 53 (1883); U.S. ConST, art. 1, § 8, cl. 8.

95. See 1 Stat. $124(1790)$.

96. See 2 Stat. 171 (1803).

97. Burrow-Giles Lithographic Co. v. Sarony, 111 U.S. 53, 57 (1884).

98. Id.

99. See United States v. Midwest Oil Co., 236 U.S. 459, 472-73 (1915).

100. See Friedman \& Smith, supra note 84, at 16 (noting that "what is beyond contest is that the opinions actually written by the Justices during this [Lochner-era] period were, for the most part, devoid of any serious attention to history or mention of the Founders").

101. See Myers v. United States, 272 U.S. 52, 190 (1926); McGrain v. Daugherty, 273 U.S. 135, 174 (1927); J.W. Hampton, Jr., \& Co. v. United States, 276 U.S. 394, 411 -12 (1928); United States v. Curtiss-Wright Export Corp., 299 U.S. 304, 328-29 (1936); Ex parte Quirin, 317 U.S. 1, $41-42$ (1942).

102. 272 U.S. 52 (1926).

103. Scalia, supra note 24 , at 850 . 
office by the President of the United States."104 Taft explained the weight of such evidence:

We have first a construction of the Constitution made by a Congress ... in which there were, as representatives and senators, a considerable number of those who had been members of the Convention that framed the Constitution and presented it for ratification. It was the Congress that launched the Government. ... It was the Congress in which Mr. Madison, one of the first in the framing of the Constitution, led also in the organization of the Government under it. 1t was a Congress whose constitutional decisions have always been regarded, as they should be regarded, as of the greatest weight in the interpretation of that fundamental instrument. ${ }^{105}$

Years later, Justice Scalia would laud Myers as "a prime example of what, in current scholarly discourse, is known as the 'originalist' approach to constitutional interpretation." 106

The Supreme Court did not use the canon from 1942 until 1970, when Chief Justice Warren Burger revived it in a case involving the Establishment Clause. ${ }^{107}$ This lapse of twenty-eight years without a single reference to the First Congress canon coincides with the rise of legal realisin in the Supreme Court and the ascendancy of the notion of the living Constitution. ${ }^{108}$ By the 1980 s, originalism had resurfaced, buoyed by the arguments of Robert Bork, Raoul Berger, and William Rehnquist. ${ }^{109}$ The return of originalism brought with it another resurgence of the First Congress canon, with the Court adopting it at least eight times between 1983 and 2003.

Along with its renewed interest in originalism, the Rehnquist Court reflected a return to the use of history to interpret the Constitution. According to one scholar, "although the Rehnquist Court has not made such general pronouncements of interpretive philosophy, in practice it has placed a great emphasis on history. In decisions involving virtually every aspect of constitutional law, the Court has stressed history to justify its conclusions." 110 As Justice Scalia explained in Printz v. United States, in which he invoked the First Congress canon, when the Constitution is silent

\footnotetext{
104. See 1 ANNALS OF CONGRESS, supra note 81 , at 473 .

105. Myers, 272 U.S. at 174-75.

106. Scalia, supra note 24, at 851-52.

107. See Walz v. Tax Comm'n, 397 U.S. 664, 678 (1970).

108. See Johnathan O'Neill, Originalism in american Law and Politics: A CONSTITUtional History 39-40 (2005).

109. See $i d$. at 129-32.

110. Erwin Chemerinsky, The Constitutional Jurisprudence of the Rehnquist Court, in THE Rehnquist Court: A ReTrospective 204 (Martin H. Belsky ed., 2002).
} 
on a particular practice, the answer "must be sought in historical understanding and practice ....",

As this Part has explained, the First Congress canon has humble beginnings, emerging from the Supreme Court's tactical retreat from partisan politics in Stuart. However, the Court has continued to employ the canon, vigorously at times, in seeking resolution of modern-day problems by consulting the actions of the First Congress. The next Part analyzes the ways in which the Court has used the canon, as well as the theoretical difficulties that its use poses.

\section{II}

\section{Problems with Interpreting the First Congress}

The First Congress canon has two key parts. In order to fix the construction of the Constitution, an act (a) must have passed through Congress near the time of the adoption, and (b) must have been met with acquiescence from the other branches of government. I will examine the interpretive difficulties that the first prong poses in this Part and address the acquiescence problem in Part III. The First Congress canon forces the Supreme Court to interpret not only recent acts of Congress to determine whether they are constitutional, but also acts of the First Congress, in order to determine the intent of that legislature. Such interpretation of actions that lie decades or even centuries removed is inherently fraught with difficulties.

First, the Supreme Court has never fully explained the logic behind invoking the First Congress as weighty evidence of the Constitution's true meaning. Is it intended to be a means of discovering the original intent of the Framers, several of whom sat in the First Congress, or is it a way of uncovering the Founding Generation's original understanding of the Constitution? If original intent is the aim, then the actions of the First Congress are at least two steps removed from the 1787 debates in Philadelphia that created the Constitution. Second, once a court navigates those logical dilemmas, the court must actually determine what the First Congress did. This poses its own interpretive difficulties, since many of the First Congress' actions are ambiguous when viewed decades or centuries later. Third, attributing meaning to those actions may often be difficult, since the actions may have resulted from political compromises or expedients that even many Framers believed to be unconstitutional. Finally, after determining either original intent or original understanding, a modern court employing the First Congress canon must then compare those legislative acts at the Founding with the present-day issue before the court. This final

111. 521 U.S. 898,905 (1997). 
action requires an additional interpretive leap that can further undermine the logic of the First Congress canon.

\section{A. Originalism and Logical Dilemmas}

\section{Original Intent vs. Original Understanding}

The First Congress canon is one of many forms of originalism, the belief that "the discoverable meaning of the Constitution at the time of its initial adoption [is] authoritative for purposes of constitutional interpretation in the present." 112 The modern version of originalism arose in the 1970s with the writings of academics such as Robert Bork and judges such as William Rehnquist. ${ }^{113}$ Early originalists focused on the original intent of the Framers when they committed the Constitution to paper. ${ }^{114}$ Partly in response to significant criticism of the attempt to divine original intent, many originalists began to focus on the "original understanding" that the framing generation held of the Constitution's meaning. ${ }^{115}$ As one originalist has argued, "It is the original understanding of the document held by its ratifiers that matters, not the original intentions of its drafters."116 Justice Scalia, for example, advocates the search for the original understanding of the Constitution. ${ }^{117}$

The Supreme Court has never been explicit whether the First Congress canon provides evidence as to the intent of the Framers or the common understanding of the founding generation. Many of the early cases hint at both. In Martin v. Hunter's Lessee, the Court attributed value to looking at the First Congress because it was comprised of "not only of men of great learning and ability, but of men who had acted a principal part in framing, supporting, or opposing that constitution ...."118 This covers not only the intent of the Framers in the First Congress, but also the understanding of those who supported or opposed the Constitution. In Myers $v$.

112. Keith E. Whittington, The New Originalism, 2 Geo. J. L. \& Pub. PoL'y 599, 599 (2004).

113. See Robert H. Bork, Neutral Principles and Some First Amendment Problems, 47 IND. L.J. 1 (1971); Robert H. Bork, The Tempting of America 143-160 (1990); William Rehnquist, The Notion of a Living Constitution, 54 TEx. L. Rev. 693 (1976).

114. See Bork, Neutral Principles and Some First Amendment Problems, supra note 113, at 17 (noting that one "proper method[] of deriving rights from the Constitution.... is to take from the document rather specific values that text or history show the framers actually to have intended . ...").

115. See Whittington, supra note 112, at 935 . For criticisms of original intent, see, for example, $\mathrm{H}$. Jefferson Powell, The Original Understanding of Original Intent, 98 HARV. L. ReV. 885 (1985); Richard S. Kay, Adherence to the Original Intentions in Constitutional Adjudication: Three Objections and Responses, 82 Nw. U. L. REv. 226 (1988), Paul Brest, The Misconceived Quest for the Original Understanding, 60 B.U. L. REV. 204 (1980).

116. John Yoo, The Powers of War and Peace: The Constitution and Foreign Affalrs AFTER $9 / 1$ I 28 (2005) (emphasis omitted).

117. See, e.g., Van Orden v. Perry, 125 S. Ct. 2854, 2865 (2005) (Scalia, J., concurring) (calling for a "return to the original meaning of the [Establishment] Clause").

118. 14 U.S. 304, 351 (1816) 
United States, Chief Justice Taft gave credence to an original intent approach, noting that the First Congress contained "a considerable number of those who had been members of the Convention that framed the Constitution and presented it for ratification." 119 Later, however, the Court explained that contemporaneous acts "when the founders of our Government and framers of our Constitution were actively participating in public affairs" would fix the constitutional meaning, thereby implicitly including the original understanding of the founders as well as the intent of the framers. ${ }^{120}$ Whichever theory undergirds the First Congress canon, the Supreme Court has never explicitly explained the reasons for its reliance on the doctrine.

The distinction is important because it is difficult to assess the reliability of the canon without understanding what the Justices who have invoked it believe that it demonstrates. Justice Clarence Thomas, for example, employed the canon in dissent in Utah v. Evans to demonstrate that the First Congress did not believe in statistical estimations for the 1790 census. ${ }^{121}$ The first Census Act, Justice Thomas wrote, provides "significant additional evidence that the Framers meant what they said in adopting the words 'actual Enumeration." "'22 Thomas appears to adopt an original intent theory, indicating that the intent of the Framers was key. ${ }^{123}$ Justice Scalia, who also dissented, notably did not join Thomas' opinion, perhaps because Scalia subscribes not to original intent but to original understanding. ${ }^{124}$ Original intent theory is vulnerable to a range of criticisms, centering around the problems that accompany attempting to divine a single intent from a body of squabbling lawmakers. ${ }^{125}$

119. 272 U.S. 52,174 (1926).

120. Id. at 175 (emphasis added).

121. 536 U.S. 452 (2002).

122. Id. at 503 .

123. Justice Thomas has on numerous other occasions referred to the original understanding of various constitutional provisions. See, e.g., United States v. Lopez, 514 U.S. 549, 585 (1995) (Thomas, J., concurring). Thomas uses historical sources very liberally, freely sampling from The Federalist, the Declaration of Independence, the ratification debates, and the secret history of the Constitutional Convention. Perhaps the more apt distinction for Justice Thomas is not between original intent and original understanding, but between the conservative originalism of Scalia and Rehnquist and his own version of liberal originalism that "argues that the Declaration of Independence articulates the philosophical ends of our nation and that the Constitution embodies the means to effectuate those ends." Scott Douglas Gerber, First Principles: The Jurisprudence of Clarence Thomas 104 (1999).

124. Regarding statutory interpretation, Justice Scalia wrote, "It is the law that governs, not the intent of the lawgiver . . Men may intend what they will; but it is only the laws that they enact which bind us." ANTONIN SCALIA, A MATter of INTERPRETATION 17 (1997). Scalia also approvingly cites Chief Justice Taft's attempt to interpret "the understanding of the First Congress" in his Myers decision. Scalia, supra note 24 , at 852 . As already explained, although the Myers opinion could be construed as supporting either original intent or original understanding, Scalia chose to focus on its support for the original understanding theory.

125. For a summary of some of the criticisms and Professor Bork's rebuttal arguments, see Bork, The TEMPTing of AMERICA 143-160, supra note 113, at 161-86. 


\section{Debates over Extrinsic Evidence}

The First Congress canon poses a number of other logical dilemmas that should be addressed, but with which the Supreme Court had never formally grappled in its decisions. One such dilemma is common to all forms of originalism, including the First Congress canon. Debates rage concerning the evidence that judges can legitimately consider in determining the original meaning of the Constitution. Evidence of original meaning could, after all, be sought from a wide variety of sources, including James Madison's notes or other documents from the Constitutional Convention, records of the ratifying conventions from the thirteen states, contemporaneous statements such as the Federalist Papers, and the actions of the First Congress. ${ }^{126}$ Each source, however, brings with it a host of interpretive difficulties. ${ }^{127}$

For example, consulting journals of the Convention has been rejected by some originalists, since the Convention was intended to be a secret affair, and no one present intended that the notes become public. ${ }^{128}$ ln fact, the Framers more or less kept their pact to remain silent about the debates of the Convention well into the early republic. ${ }^{129}$ Convention delegate Rufus King even suggested that any journals of the Convention be destroyed so that they could not be put to "a bad use ... by those who would wish to prevent the adoption of the Constitution." ${ }^{130}$ Furthermore, the records of the Convention are "defective in varying degrees" because of inaccuracy, incompleteness, or incoherence. ${ }^{131}$

The records of the ratifying conventions may be a better source, since the states gave the Constitution the force of supreme law, not the scribblers

126. Accounts of the Convention include the official journal by Secretary William Jackson, the notes of Robert Yates, and Madison's notes. Journal, ACts and Proceedings of the Convention, Assembled at Philadelphia, Monday, May I4 (Thomas B. Wait 1819); Secret Proceedings and Debates of the Convention Assembled at Philadelphia, in the Year 1787, for the Purpose of Forming the Constitution of the United States Of America (1821); The Papers of James MADISON (H. Gilpin ed., 1842). The State ratifying convention records can be found in THE DeBATES in the Several State Conventions, on the adoption of the Federal Constitution, as Recommended by the General Convention at Philadelphia, In 1787 (Jonathon Elliot ed., 1827$30)$.

127. See generally James H. Hutson, The Creation of the Constitution: The Integrity of the Documentary Record, 65 TEx. L. REv. 1 (1986).

128. See, e.g., Martin S. Flaherty, The Most Dangerous Branch, 105 YALE L.J. 1725, I801-02 (1996); Bruce A. Ackerman, Discovering the Constitution, 93 Y ALE L.J. 1013, 1059 n.80 (1984). For a counterpoint, which argues that use of the secret drafting history of the Convention is perfectly appropriate, see Vasan Kesavan \& Michael Stokes Paulsen, The Interpretive Force of the Constitution's Secret Drafting History, 91 GEo. L.J. 1113 (2003).

129. Only in 1819 did Congress authorize the publication of William Jackson's official journal of the Convention. See 3 Stat. 475 (1818). Before that, no records of the proceedings had been published. Hutson, supra note 127, at 2.

130. 2 Records of the Federal Convention of 1787, at 648 (Max Farrand ed., 1911) [hereinafter 2 CONVENTION RECORDS].

131. Hutson, supra note 127 , at 38 . 
who pieced it together in Philadelphia. ${ }^{132}$ However, records are often scanty from the ratifying conventions. In addition, various states and individuals ratified the Constitution for different reasons, thereby negating the interpretive clarity of those sources. ${ }^{133}$ The Federalist, which Justice Scalia relies on as evidence of original understanding, ${ }^{134}$ is the work of three fierce advocates-Alexander Hamilton, James Madison, and John Jay-who sought to convince a skeptical New York audience and allay their fcars. As such, the arguments in The Federalist are naturally skewed toward those that would sway New Yorkers and away from those, such as the acceptance of slavery, that would more likely sway South Carolinians. ${ }^{135}$

\section{Divining the Framers' "Intent"}

The First Congress canon brings a similar set of logical conundrums. For example, one of the rationales for the First Congress canon is that many of its members were present at the Constitutional Convention. ${ }^{136}$ In fact, nine representatives and eleven senators in the First Congress helped write the Constitution in Philadelphia in $1787 .{ }^{137}$ These Framers constituted $13.6 \%$ of the House and $42.3 \%$ of the Senate. Although their numbers were sizeable in the Senate, they did not constitute a majority, and Framers formed only a small minority in the House. Were their numbers sufficient to give any and all actions of Congress the stamp of constitutional approval? Since records on the First Congress are scarce, we do not know how these Framers voted on most of the key acts of Congress, nor do we know what they said in various debates. It is possible that the nine Framers in the House believed a bill to be unconstitutional, yet were outvoted by their non-Framing brethren. Should such an act receive the deference of the Supreme Court under the First Congress canon?

132. See Whittington, supra note 112, at 610 ("It is the adoption of the text by the public that renders the text authoritative, not its drafting by particular individuals."). For an example of a practical use of records from ratifying conventions, see Yoo, supra note 116, at 88-141.

133. See Jack N. Rakove, Original Meanings: Politics and ldeas in the Making of the Constitution 15-17 (1996).

134. See SCalia, supra note 124, at 38 ("1 will consult the writings of some men who happened to be delegates to the Constitutional Convention-Hamilton's and Madison's writings in The Federalist, for example. 1 do so ... because their writings, like those of other intelligent and informed people of the time, display how the text of the Constitution was originally understood."). For an excellent example of his use of evidence from The Federalist as virtually dispositive of an issue, see Printz $\mathrm{v}$. United States, 521 U.S. 898, 910-24 (U.S. 1997) (using evidence from The Federalist to demonstrate that the Framers did not believe that the federal government could commandeer state officials).

135. See RaKove, supra note 133, at 15 (noting that "for all its virtues, The Federalist presents only one facet of the wide-ranging debate that erupted with the publication of the Constitution").

136. See, e.g., Burrow-Giles Lithographic Co. v. Sarony, 111 U.S. 53, 57 (1884) ("The construction placed upon the Constitution ... by the men who were contemporary with its formation, many of whom were members of the convention which framed it, is of itself entitled to very great weight ....").

137. See Bowsher v. Synar, 478 U.S. 7I 4, 724 n.3 (1986). 
Furthermore, three of the Framers in the First Congress did not sign the final Constitution. Caleb Strong, a senator from Massachusetts, returned home because of illness and did not sign the Constitution, although he fought for it in the Massachusetts state ratifying convention and presumably would have signed if he had the chance. ${ }^{138}$ Oliver Ellsworth, senator from Connecticut and future Chief Justice of the Supreme Court, also did not sign but instead returned to New Haven shortly before the signing ceremony. ${ }^{139}$ Massachusetts Representative Elbridge Gerry refused to sign the document on a number of grounds, including the three-fifths clause governing the counting of slaves, his belief that Congress could establish monopolies under the Commerce Clause, and the fact that the vice president would preside over the Senate. ${ }^{140}$ Since these Framers did not sign the Constitution, and since Gerry actively refused to sign it, should their views on the meaning of the Constitution carry equal weight with those who did sign?

The First Congress canon assumes that the Framers present in the two chambers infused the proceedings with a superior understanding of the intricacies of the Constitution. However, the Framers themselves often disagreed about the meaning of the document. Alexander Hamilton and James Madison, the two primary authors of the Federalist Papers, later split on the constitutionality of a variety of congressional actions, including the assumption of state debt, the creation of a federal bank, and the role of the House in the ratification of treaties. ${ }^{141}$ Although initially allied, the two clashed repeatedly during the 1790 s, coming to radically different conclusions about what the Constitution allowed. Oliver Ellsworth and William Paterson, both Framers who later served in the first Senate and the Supreme Court, often sparred during debates over the Judiciary Act of 1789, indicating that they brought different understandings of the Constitution from their time in Philadelphia. ${ }^{142}$ Furthermore, the only act of the First Congress overturned in part as unconstitutional by the Supreme Court, the Judiciary Act of 1789, was in fact largely written by a Framer, Oliver Ellsworth. ${ }^{143}$ Senator William Maclay complained of Ellsworth's attachment to the judiciary bill: "This vile bill is a child of his, and he defends it

\footnotetext{
138. Biographical Directory of the United States Congress, http://bioguide.congress.gov/biosearch/biosearch.asp (last visited February 8, 2006).

139. See 2 CONVENTION ReCORDS, supra note 130, at 587. It is not known why Ellsworth did not sign the Constitution. See George Van Santvoord, Sketches of the Lives, Times and Judicial. Services of the Chief Justices of the Supreme Court of The United States 262 (1882). He certainly supported it and forcefully advocated it in the Connecticut ratifying convention. See Casto, supra note 60 , at 96.

140. 2 Convention Records, supra note 130, at 632-33; Henry Flanders, 2 The Lives and Times of the Chief Justices of the Supreme Court of the United States 143 (1875)

141. See Ron Chernow, Alexander Hamilton 304-05, 349, 496-97 (2004).

142. See William Maclay, Journal of William Maclay 1789-1791, at 92-94 (1890).

143. Keith Bernard Umbreit, Our Eleven Chief Justices 99 (1938).
} 
with the care of a parent, even with wrath and anger." ${ }^{\prime 44}$ The fact that a Framer was the principle author of an act that the Supreme Court later invalidated should undermine a pillar of the First Congress canon.

In the First Congress, members showed little of the deference toward the Framers among them that later Supreme Courts would show. ${ }^{145}$ For example, when debating whether the Constitution granted the President the right to remove executive officers, Representative Alexander Smith took exception to the views of two Framers, Roger Sherman and James Madison. Smith explained that Sherman's arguments "come from a gentleman whom I always hear with pleasure, on account on his sound reasoning and perspicuity of expression; but, in this case, I differ from him widely." 146 Non-framing members of the First Congress thereby felt free to contradict the Framers that graced their legislature on constitutional issues. Similarly, the Framers in the First Congress did not indicate that their presence at the convention gave them any superior insight into the dictates of the Constitution ${ }^{147}$ The great deference that the Supreme Court has at times afforded the Framers in the First Congress was not reflected in the First Congress itself.

Even if the presence of Framers gives the acts of the First Congress some immunity from constitutional second-guessing from the judiciary, the Supreme Court has at times pushed this logic to its limit. As the years passed in the early republic, the number of Framers present in the Congress began to dwindle. At the same time, the Supreme Court began to cite to the initial several Congresses as contemporaries of the Convention. ${ }^{148}$ In 1842, the Court invoked the canon when referring to the Fugitive Slave Act, which passed at the very end of the Second Congress in February 1793. ${ }^{149}$ This Act, passed six years after the Constitutional Convention, arguably still constitutes a "contemporaneous exposition" of the Constitution, as the Court asserted. ${ }^{150}$ In The Laura, however, the Court found "contemporary" evidence in congressional acts passed in 1797 and in $1800 .{ }^{151}$ From the perspective of almost a century later, when Justice John Harlan wrote the Laura decision, 1797 and 1800 may have appeared contemporaneous with the 1787 Constitution, but they were far from it.

\footnotetext{
144. MACLAY, supra note 142 , at 91 .

145. Kent Greenfield, Original Penumbras: Constitutional Interpretation in the First Year of Congress, 26 Conn. L. REv. 79, 101 (1993).

146. I ANNALS OF CONGRESs, supra note 81, at 538.

147. Greenfield, supra note 145 , at 135 .

148. According to historian Jack Rakove, "The greater the remove in time from the moment of founding, the greater the inclination to collapse the distinct phases of framing, ratifying, and implementing the Constitution into one composite process of original interpretation." RAKOvE, supra note 133 , at 9 .

149. See Prigg v. Pennsylvania, 41 U.S. 539 (1842).

150. Id.

151. 114 U.S. $411,416(1885)$.
} 
By the end of the eighteenth century, the new republic had changed significantly since the Constitutional Convention. Most importantly, the perspectives of the Framers fractured as they split between the Federalist and the Republican parties. In Knowlton v. Moore, the Supreme Court, however, rationalized the increasing distance between the constitutional passage and the congressional acts that it cited as contemporary expositions. In considering a 1797 tax bill to be contemporaneous with the Convention, the Court explained:

Even the then members of the Congress who had not been delegates to the convention, which framed the Constitution, must have had a keen appreciation of the influences which had shaped the Constitution and the restrictions which it embodied, since all questions which related to the Constitution and its adoption must have been, at that early date, vividly impressed on their minds. ${ }^{152}$

The Court continued to push the temporal boundaries of the First Congress doctrine. In Walz v. Tax Commission, the Court relied on an 1802 tax statute to uphold a New York statute giving tax breaks to church properties. ${ }^{153}$ By 1802 , however, only five of the 159 members of Congress had also attended the Constitutional Convention, amounting to only $3.1 \%$ of the Congress. ${ }^{154}$ All of them, moreover, were senators, leaving the House bereft of Framers. In Ex Parte Quirin, the Court cited an 1806 congressional act as contemporary precedent. ${ }^{155}$ By 1806 , however, only two Framers remained in the Congress-Abraham Baldwin and Nicholas Gilman-and both in the Senate. ${ }^{156}$ In fact, these two Framers were now matched by two descendents of Framers: James Madison Broom (son of Jacob Broom) and Henry Walter Livingston (grand nephew of William Livingston). ${ }^{157}$ If Thomas Mann Randolph and John Wayles Eppes (both sons-in-law of Thomas Jefferson), John Quincy Adams (son of John Adams), and John Asheford Bayward (son-in-law of Framer Richard Bassett) can also be counted, by I806 the next generation had far exceeded the founding generation in Congress. ${ }^{158}$

\footnotetext{
152. Knowlton v. Moore, 178 U.S. 41, 56 (1900).

153. 397 U.S. $664,678(1970)$.

154. The Framers included Abraham Baldwin, Pierce Butler, Jonathon Dayton, Gouverneur Morris, and Charles Pinkney. See Blographical Directory of the United States Congress, supra note 138 .

155. 317 U.S. 1,41 (1942)

156. BIographical Directory of THE UNited States Congress, supra note 138.

157. Id.

158. Id. Jefferson and Adams admittedly are not Framers, since they were not present at the Convention. But they were nevertheless key members of the founding generation.
} 


\section{B. Two Steps Removed: Problems of Interpreting Past Actions}

Professional historians understand that interpreting the past is akin to viewing the world through a distorting prism. The further in time historians are from their subject of study and the fewer perspectives they can study, the more opaque the prism becomes. For example, Madison's notes and other eyewitness documents are the best evidence of the original intent of the men who gathered in Philadelphia to frame the new Constitution. Even so, historians must interpret the events of Philadelphia through the prism of James Madison's eyes and ears, which shaped his narrative and colored his perceptions of the events around him. The passage of more than two centuries since Madison penned his notes imposes additional filters, so that historians must attempt to avoid reading Madison's notes through the lens of the present. As Justice Robert Jackson famously wrote, "Just what our forefathers did envision, or would have envisioned had they foreseen modern conditions, must be divined from materials almost as enigmatic as the dreams Joseph was called upon to interpret for Pharaoh."159

Interpreting Madison's notes removes the historian one step from the actual events in Philadelphia in 1787, from Madison's eyes to those of the modern-day historian. Even if one accepts the notion that the presence of Framers helps guarantee the constitutionality of congressional acts, interpreting original understanding through acts of the First Congress is to view the Constitution one additional step removed. This imposes another prism through which this history must be viewed. From the text of bills passed by the early Congresses, judges using the First Congress canon attempt to divine what those members of Congress believed about the Constitution. This removes the Constitution at least two steps from modern interpreters, from the eyes of the Framers to those of the First Congressmen to the modern judge or historian. Each step imposes an additional prism that makes modern interpretation fraught with potential distortion.

Even if what is relevant is not the original intent of the Framers, but instead the original understanding of the Constitution's contemporaries, including non-Framers in the Congress, the modern interpreter necessarily views the acts of the First Congress through a murky lens. Modern judges must discern how those acts represent what the original congressmen thought about the Constitution. Acts pass through any Congress for a variety of reasons, and the First Congress was not immune from passing bills that flirted with unconstitutionality. A member of Congress voting to pass a bill may not have been convinced that it was constitutional, or simply may not have considered the constitutional implications. Even though the First Congress was highly attuned to constitutional limits, the document was still very fresh, and no member of Congress could yet have digested all

159. Youngstown Sheet \& Tube Co. v. Sawyer, 343 U.S. 579, 634 (1952). 
its implications, many of which are still coming to light more than two centuries later.

\section{Cooley: The Competing Interpretation Problem}

Beyond the theoretical difficulty of divining insight into the Constitution through the acts of the First Congress, the canon forces modern courts to interpret acts of the first legislature that are often ambiguous and that left little in the historical record. The variety of potential interpretations leaves the Justices with little but their own predispositions to guide them in selecting the correct one. As a result, in some cases Justices have lined up on opposite ends of a Court decision, each side invoking the acts of the First Congress as supporting its case. The 1852 case of Cooley $v$. Board of Wardens illustrates this challenge. ${ }^{160}$ The case posed the question of whether a state could regulate pilotage in its navigable waters. An 1803 Pennsylvania law required that all ships arriving or departing from Philadelphia hire a local pilot. The master of a ship that failed to do so would incur a penalty that would be forwarded to a relief society for "distressed and decayed pilots." 161 When the schooner Consul left Philadelphia on its way to New York City without hiring a pilot, the port's board of wardens fined the vessel's master, Aaron B. Cooley. ${ }^{162}$

Rather than pay the fine, Cooley challenged the constitutionality of the state law. He argued that the pilotage requirement violated Article I of the Constitution in three different ways. First, under section ten, states could not impose "any Imposts or Duties on Imports or Exports." 163 The Court dismissed this claim, holding that a requirement for paying a pilot did not constitute an import or duty on trade goods. ${ }^{164}$ Second, Article 1, section nine required that "Vessels bound to, or from, one State, [shall not] be obliged to enter, clear, or pay Duties in another." 165 The Court again dismissed the claim under the same logic, that hiring a pilot was not a duty.

However, the Court went on to note that "similar laws have existed and been practised on in the [s]tates since the adoption of the federal Constitution." 166 In particular, in 1789, the First Congress declared that

all pilots in the bays, inlets, rivers, harbors and ports of the United States, shall continue to be regulated in conformity with the existing laws of the States respectively wherein such pilots may be, or with such laws at the States may respectively hereafter enact for

\footnotetext{
160. 53 U.S. 299 (1852).

161. Id. at 311,313 .

162. Id. at 299.

163. U.S. Const. art. $1, \S 10$

164. Cooley, 53 U.S. at 314.

165. U.S. Const. art. $1, \S 9$.

166. Cooley, 53 U.S. at 315.
} 
the purpose, until further legislative provision shall be made by Congress. ${ }^{167}$

The Court then invoked the First Congress canon, holding that "this contemporaneous construction of the Constitution, since acted on with such uniformity in a matter of much public interest and importance, is entitled to great weight, in determining whether such a law is repugnant to the Constitution ...."168

Finally, Cooley argued that the pilotage fees offended the Commerce Clause, which gave Congress sole authority to regulate interstate commerce. ${ }^{169}$ The Court agreed that the coastal trade, in which the Consul had been engaged, constituted interstate commerce that Congress could regulate. ${ }^{170}$ However, the Constitution did not forbid the Congress from delegating these powers, as it did with the 1789 Act. As long as the Pennsylvania statute did not usurp Congress' ability to regulate interstate commerce, the statute did not violate the Constitution. ${ }^{171}$

The majority interpreted the 1789 Act as temporarily delegating its Commerce Clause power to states, thereby recognizing the ability of states to regulate the coastal trade. Justices John McLean and James Moore Wayne dissented. They agreed that the actions of the First Congress dictated the result in the case, but they disagreed with the Court's interpretation of those actions. The dissenters, however, interpreted the Act as adopting the regulations of the states wholesale, thereby asserting Congress' exclusive right to regulate interstate commerce. ${ }^{172}$ "Congress may adopt the laws of a State, but it cannot enable a State to legislate."173

So which was it? Did Congress delegate the powers to the States, or did it adopt State regulations wholesale? The text of the 1789 Act gives few clues, explaining only that pilots "shall continue to be regulated in conformity with the existing laws of the States respectively ..." 174 If, as the dissenters argue, members of the First Congress saw their Act as preempting the field of piloting, then Pennsylvania's 1803 law could have no effect. If however, as the Court held, Congress intended to allow states to continue regulating pilotage until Congress could get around to asserting its right to regulate, then the I803 law would be constitutional. Although

167. Act of Aug. 7, 1789, 1 Stat. 53.

168. Cooley, 53 U.S. at 315. The Court cited Stuart v. Laird, Martin v. Hunter's Lessee, Cohens v. Virginia, and Prigg v. Pennsylvania to support this proposition.

169. Cooley, 53 U.S. at 315.

170. Id. at $316-17$

171. Id. at 320 .

172. Id. at 322 .

173. Id. at 323 .

174. Act of Aug. 7, 1789, 1 Stat. 53. 
both the majority and the dissent adopted the First Congress canon, they split on the meaning of the First Congress' actions. ${ }^{175}$

One of the great difficulties in interpreting the acts of the First Congress is that records are incomplete. Contemporary evidence of the congressional proceedings is "distressingly skeletal." "176 Although the Constitution requires that the Congress "keep a Journal of its Proceedings," 177 neither chamber faithfully did so in the early years. ${ }^{178}$ The Senate, for example, decided to maintain secrecy about its proceedings so that Senators could participate without fear of undue public scrutiny. ${ }^{179}$ The upper house did not open its debates to the public until December $1795 .^{180}$ The only documentary evidence of Senate statements comes from the personal notes of Senator William Maclay of Pennsylvania, although these are at best spotty, and Maclay served only a two-year term. ${ }^{181}$ The House and Senate journals report only the minutes of the various meetings, indicating when debates were held on particular bills, but do not record the substance of the debates. ${ }^{182}$

House leaders, at least, allowed commercial reporters to record and publish the debates and sell them. Between 1834 and 1856, Congress collected these various newspaper accounts and compiled them into The Debates and Proceedings in the Congress of the United States, more commonly known as the Annals of Congress. ${ }^{183}$ Although these contain fuller accounts than those in the official journals, the reporters generally recorded only abbreviations of House debates and included numerous errors. ${ }^{184}$ One reporter, for example, recorded a bill regulating harbors as one regulating barbers. ${ }^{185}$ The House refused to sanction these private works so that the many errors would not be attributed to the members. ${ }^{186}$ The Annals tend to

175. The dissent did not explicitly mention the canon, but its explication of the actions of the First Congress as determinative indicates its assent to the canon.

176. Roy Swanstrom, The United States Senate, 1789-i 80 i 2 (1985).

177. U.S. CONST. art. $1, \S 5$.

178. See David P. Currie, The Constitution in Congress: The Federalist Period, 1789 I 80110 nn.26-27 (1997).

179. According to rule 11 of the first Senate rules, "Inviolable seerecy shall be observed with respect to all matters transacted in the Senate while the doors are shut..." MACLAY, supra note 142, at xiv.

180. SWANSTROM, supra note 176 , at 3 .

181. See MaClay, supra note 142; Biographical Directory of the United States Congress, http://bioguide.eongress.gov.

182. See 1 Journal of the House of Representatives of the United States, Being the First SEsSion of Congress (1826) [hereinafter House Journal]; 1 Journal of the First Session of the Senate of the United States of America (1820) [hereinafter Senate Journal].

183. See generally ANNALS OF CONGRESS, supra note 81 .

184. These reporters included ThOmas Lloyd's CONGRESSIONAL REGISTER and John FenNo's Gazette of the UNITED States. See CURRIE, supra note 178, at 10-11 nn.29 \& 31 .

185. CURRIE, supra note 178 , at 10, n.29.

186. Id. 
give only a rough sketch of what the House did on a particular day, with little indication of the debates that occurred.

In attempting to determine the legislative intent behind the adoption of state pilotage laws in Cooley v. Board of Wardens, the Court could not count on the legislative history of the First Congress to enlighten them. ${ }^{187}$ For example, when the Senate passed the bill on pilotage, the report noted only, "[a]n act for the-establishment and support of light-houses, beacons, and buoys ... concurr[ed in with amendments]... was carried to the House of Representatives [by the Secretary]." 188 This hardly gave the Court sufficient information to determine the meaning behind the adoption of state pilotage regulations. As a result, the Court split in two, each side adopting a plausible reading of the Act. Coming from such meager historical resources, the ultimate result in Cooley revealed less about the actual intent of the First Congress than it did about the current Justices themselves. Since the Justices had little or nothing of historical import to work with, the only principled means of resolving the dispute was to see which side could line up a majority of votes.

In more modern times, the Court that debated the origins of the Copyright Act of 1790 in Eldred v. Ashcroft also had little information from the First Congress with which to work. The House journal indicates that the bill was read for the first time in the House on January 28, 1790, and that it was sent to a committee with the instructions to "insert a clause or clauses for giving effectual encouragement to the introduction of useful arts from foreign countries." 189 The journal then charts the progress of the bill through the House, indicating when it was read a second or third time, but never again does the journal indicate anything of substance. The Senate journal recorded almost nothing about its debate on the copyright bill. ${ }^{190}$ The Annals of Congress provide no detail on the debates over the bill. ${ }^{191}$

187. This assumes, of course, that the legislative history would be an acceptable form of evidence for the justices to employ. Justice Scalia famously deplores the use of legislative history. For example, see Scalia's artful concurrence in Intel Corp. v. Advanced Micro Devices, in which he attacked the use of a Senate Report as evidence of a statutory interpretation:

That being so, it is not only (as 1 think) improper but also quite unnecessary to seek repeated support in the words of a Senate Committee Report-which, as far as we know, not even the full committee, much less the full Senate, much much less the House, and much much much less the President who signed the bill, agreed with. Since, moreover, I have not read the entire so-called legislative history, and have no need or desire to do so, so far as 1 know the statements of the Senate Report may be contradicted elsewhere.

542 U.S. 241, 267 (2004).

188. 1 Senate Journal, supra note 182, at 56. Section 4 of that Act dealt with pilotage laws. See 1 Stat. 53.

189. 1 House Journal, supra note 182 , at 149.

190. See, e.g., 1 Documentary History of the First Federal Congress of the United States of America 310 n.58 (Linda Grant De Pauw ed., 1972) (noting that the only substantive indication of the Senate debates over the copyright bill consisted of a few edits of the bill's language).

191. See, e.g., 1 ANNALS OF CONGRESS, supra note 81, at 1143. 
Such limited information gives modern judges little guidance in deciding between constitutional interpretations.

\section{Myers: The Congressional Understanding Problem}

Even if the bills passed by the early Congresses are not as ambiguous as the one in Cooley, a further interpretive difficulty arises in determining why Congress passed such a measure and whether members of Congress believed it to be constitutional. In Myers v. United States, the Court examined the constitutionality of an 1876 statute that allowed the President to remove postmasters only "by and with the advice and consent of the Senate." ${ }^{192}$ In 1920, Frank Myers, the postmaster of Portland, Oregon, was removed unilaterally from his position by the Postmaster General six months short of the end of his four-year term. ${ }^{193}$ Myers sued the government for back wages, arguing that he could not be removed without Senate consent. The Constitution requires Senate approval for the installment of executive officers, but says nothing about their removal. ${ }^{194}$

For evidence of what the Constitution intended, the Court looked at the acts of the First Congress in establishing the executive departments. In 1789, Congress debated a bill to establish a Department of Foreign Affairs, including a provision that the officers were "to be removable from office by the President of the United States." 195 That provision divided the members over which branch originally possessed the power to remove officers. The language appeared to be a grant of power to the executive, but was the power Congress' to grant? Some members, such as Madison, believed that the President could already remove executive officers at his discretion. ${ }^{196}$ Others believed that only Congress could remove officers. ${ }^{197}$ Still others believed that the President could remove officers only with the consent of the Senate. ${ }^{198}$ In the final compromise, the House first added a phrase implying that the President held the power to remove and then deleted the original provision. ${ }^{199}$

192. Myers v. United States, 272 U.S. 52, 140 (1926); Act of Congress of July 12, 1876, 19 Stat. 78.

193. Myers, 272 U.S. at 106.

194. U.S. CONST. art II, $\S 2$.

195. See 1 ANNALS OF Congress, supra note 81, at 473.

196. See id. at 514-21 (recording the floor arguments of James Madison).

197. See id. at 510-11 (recording the floor arguments of Roger Sherman)

198. See id. at 521-25 (recording the floor arguments of Elbridge Gerry).

199. Egbert Benson, who agreed with Madison that the President already possessed the full power to remove officers, introduced the first amendment on June 22, 1789, that the chief clerk of the new department would take custody of all the department's papers "whenever the principal officer shall be removed from office by the President of the United States." Id. at 601 . This amendment passed by a vote of thirty to eighteen. $J d$. at 603 . The second amendment, deleting the original controversial provision, passed by a vote of thirty-one to scventeen. Id. at 608 . 
The Myers Court took this as irrefutable evidence that "there is not the slightest doubt, after an examination of the record, that the vote was, and was intended to be, a legislative declaration that the power to remove officers appointed by the President and the Senate vested in the president alone . . . "200 Chief Justice William Howard Taft, writing for the majority, emphasized the weight that such evidence should receive:

We have first a construction of the Constitution made by a Congress ... in which there were, as representatives and senators, a considerable number of those who had been members of the Convention that framed the Constitution and presented it for ratification. ... It was the Congress in which Mr. Madison, one of the first in the framing of the Constitution, led also in the organization of the Government under it. It was a Congress whose constitutional decisions have always been regarded, as they should be regarded, as of the greatest weight in the interpretation of that fundamental instrument. ${ }^{201}$

A closer examination of the 1789 vote, however, reveals a more complex picture than Chief Justice Taft admitted, undermining the force of the evidence relied upon by the Court. If the Court looked at the actions of the First Congress because the presence of Framers imbued it with special authority, then a closer look at the individual Framers involved belies that belief. The nine Framers present in the House of Representatives in 1789 formed very different conclusions about the power of removal, with at least one Framer in each of the three schools of thought. Framer James Madison believed that only the President could remove officers. Because Article II invested all executive powers in the President and required him to faithfully execute the laws, he must be able to exercise complete control over his officers. ${ }^{202}$ Framer Elbridge Gerry argued that to give the President full power to remove Treasury officers would infringe on the Senate's power to consent in appointments and the Congress's power to control appropriations. ${ }^{203}$ Framer Roger Sherman argued that "[a]s the officer is the mere creature of the Legislature, we may form it under such regulations as we please" and can remove the officer at will. ${ }^{204}$ The Framers all came to radically different conclusions, despite their shared presence at Philadelphia. When the House finally voted on the amendment to remove the provision conferring power to remove officers on the President, five Framers voted for the amendment, and three voted against it. ${ }^{205}$ This hardly shows the clarity of opinion that Chief Justice Taft implied in Myers.

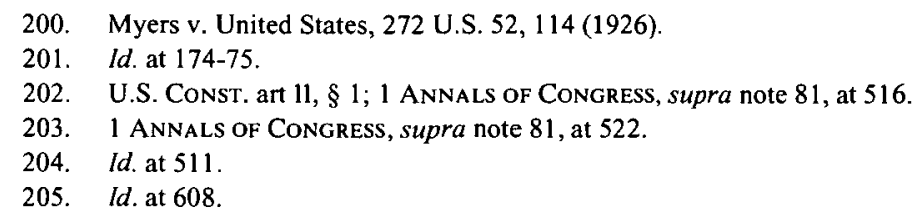


Furthermore, the final result in the 1789 decision may have been one that a majority of members of Congress considered unconstitutional. The 1789 vote provides a classic example of Arrow's Theorem, the idea that a vote involving a three-way split of opinion can create a majority result that no majority actually supports. ${ }^{206}$ Professor Rebecca Brown has explained how this worked in the decision of 1789 :

[James Madison] led a group, call it $A$, who believed that the Constitution granted removal power to the President alone. He had two groups of opponents: $B$, who thought that Congress, rather than the Constitution, determined the issue, and $C$, who thought that the Constitution provided for joint power of removal shared by the executive branch and the Senate.... Madison engineered two votes on amendments. One vote divided his two opponent groups one way ( $A$ was joined by $B$ and opposed by $C$ ); the second vote divided them the other way ( $A$ was joined by $C$ and opposed by $B$ ). The result was that Madison's group, $A$, was the only faction to get its way both times, so its view prevailed-even though there was no majority that supported both amendments proposed by Madison. The combined effect of the amendments was to create a congressional "decision" suggesting that, as a constitutional matter, the President has the sole power to remove executive officials. ${ }^{207}$

Although Chief Justice Taft explained that it was "very clear from this history" that the Framers believed that the President held the sole power to remove officers, the history is anything but clear. ${ }^{208}$ Not only did the Framers themselves split rather evenly over the question, but the ultimate decision by the House of Representatives could not even command a majority vote without the clever manipulation of James Madison. ${ }^{209}$ In other words, decisions of the First Congress may not provide the historical insight that later Court interpreters would like to believe. Although the Myers Court's superficial reading of the decision of I789 leads it to the "very clear" conclusion that the First Congress believed the President had the sole authority to remove officials, a more nuanced reading shows a fractured Congress that could not come to a solid conclusion on the issue. Such interpretive perils, in which the Court attempts to divine the intent of

206. See Brown, supra note 13 at 186-87; Note: Should the Supreme Court Presume that Congress Acts Constitutionally?, supra note 13 at 1809 . For an explanation of the Arrow Theorem, see DANIEL A. Farber \& Philip P. Frickey, Law and Public Choice: A Critical Introduction 38-39 (1991). The Arrow Theorem comes from Kenneth ARrow, Social Choice and Individual Values (2d ed. 1963).

207. Brown, supra note 13 , at 186-87.

208. Myers v. United States, 272 U.S. 52, 114 (1926).

209. The records of the Senate, meanwhile, are characteristically reticent about the debate. The Senate debated whether to take out the House's amending language implying that the President had the power to remove officers, and Vice President John Adams broke a tie vote of ten to ten to keep the language in the bill. See MACLAY, supra note 142, at 114-16. 
congressional decisions made centuries in the past, are inherent in the First Congress canon.

\section{Burrow-Giles Lithographic Co.: The Apples and Oranges Problem}

Once the Supreme Court has determined what the First Congress actually did and the intent behind those actions, it can then compare them with the statute or practice in the present whose constitutionality is being questioned. This step, however, causes further interpretive difficulties.

In Burrow-Giles Lithographic Company v. Sarony, the Supreme Court examined whether photographs could be protected by copyright, as provided in the 1865 Copyright Act. ${ }^{210}$ In January I882, photographer Napoleon Sarony took a series of twenty photographs of the writer Oscar Wilde. ${ }^{211}$ As was common in the 1880 s, Burrow-Giles reproduced one of the photographs for a mass audience, printing 85,000 copies, without ever receiving permission from the photographer, and Sarony sued. ${ }^{212}$ Burrow-Giles argued in its defense that the I865 Copyright Act, which extended protection to photographs, violated the constitutional provision that copyright cover "writings" done by "authors."213 A serious constitutional argument can be made here. Justice William O. Douglas, for example, argued in dissent in 1954 that a statuette of Balinese dancers likely did not qualify as a protected writing, despite congressional copyright protection. ${ }^{214}$ "The Copyright Office has supplied us with a long list of such articles which have been copyrighted-statuettes, book ends, clocks, lamps, door knockers, candlesticks, inkstands, chandeliers, piggy banks, sundials, salt and pepper shakers, fish bowls, casseroles, and ash trays," Douglas wrote. "Perhaps these are all 'writings' in the constitutional sense. But to me, at least, they are not obviously so."215 The same logic would apply to photographs.

Nothing in the history of the copyright clause indicated that a photograph could qualify as a writing. The 1709 Statute of Anne in Britain, on which later American legislators based their copyright statute, ${ }^{216}$ extended protection only to books and other writings. ${ }^{217}$ Twelve of the American colonies provided copyright protection, but nine of them limited protection

\footnotetext{
210. Burrow-Giles Lithographic Co. v. Sarony, 111 U.S. 53 (1884); Act of March 3, 1865, 13 Stat. 540.

211. See Jane M. Gaines, Contested Culture: The Image, the Volce, and the Law 52 (1991).

212. Id.

213. 111 U.S. at 53.

214. Mazer v. Stein, 347 U.S. 201, 221 (1954), superseded by statute, 37 C.F.R. 202.10(c) (1959), as recognized in Fabrica, Inc. v. El Dorado Corp., 697 F.2d 890 (9th Cir. 1983).

215. Id. at 220-21.

216. See Hellmut lehmann-Haupt, The Book in America 93 (1939).

217. 8 Anne, c. 19 (1709).
} 
to books and pamphlets. ${ }^{218}$ Only North Carolina, Georgia, and Connecticut pushed copyright protection to cover maps and charts as well. ${ }^{219}$ The Constitutional Convention gives no indication of the Framers' intent, since no debate on the Copyright Clause was recorded. Under the new Constitution, the First Congress gave copyright protection only to "any map, chart, book or books."220 Again, the members of Congress recorded no debate about the intended scope of protection. In 1802, Congress broadened protection to include those "who shall invent and design, engrave, etch or work . . . any historical or other print . . .."221

In Burrow-Giles, the Supreme Court held that copyright could extend to photographs. It outlined the copyright statutes passed in 1790 and 1802, whose definitions the Court found "almost conclusive" because of its proximity to the Constitution. ${ }^{222}$ As for the constitutional text that copyright extends to "authors" of "writings," the Court concluded that "[b]oth these words are susceptible of a more enlarged definition ...." An author, for example, could be seen as "he to whom anything owes its origin; originator; maker; one who completes a work of science or literature." 223 The Court, however, had a more difficult time finding a definition of writing that would include a photograph. "By writings in that clause is meant the literary productions of those authors, and Congress very properly has declared these to include all forms of writmg, printing, engraving, etching, $\& \mathrm{c}$., [sic] by which the ideas in the mind of the author are given visible expression."224 Its only evidence that Congress acted "very properly" was the fact that the First Congress, replete with Framers, passed a copyright act giving protection to maps and charts.

The Burrow-Giles decision remains troubling, in part because it effectively blocked many constitutional challenges to copyright protection. ${ }^{225}$ The Court evinces no theory for why a photograph might be considered a writing beyond the fact that Congress has declared it to be one, as shown by the 1790 protection of maps and charts. But is a photograph really a fair equivalent to a map or chart, or is this comparing apples to oranges? Maps and charts at the time were drawn by hand, using the same process by which someone would write a book. Even the 1802 extension of copyright

218. See Copyright: Study of the Term "Writings" in the Copyright Clause of the Constitution, 31 N.Y.U. L. REv. 1263, 1265 (1956).

219. Id.

220. 1 Stat. 124 (1790).

221. 2 Stat. 171 (1802).

222. 111 U.S. at 57.

223. Id at $57-58$.

224. Id. at 58.

225. See Copyright, supra note 218 , at 1284 (noting the "accepted view that, at least since the decision of Burrow-Giles in 1884, the question [of the "writing" requirement] is settled and it has been "made clear that "writings" was not limited to chirography and typography" (quoting Mazer v. Stein, 347 U.S. 201, 210 n.15(1954)). 
to etchings and engravings stretches the meaning only modestly. But a photograph is a mechanical production involving nothing comparable to the process of writing. Napoleon Sarony arguably can be considered the author of the photograph in a broader sense of the word. But a photograph can only be considered a constitutional writing by taking two questionable steps: (a) assuming based solely on the presence of Framers that the First Congress was justified in giving protection to maps and charts, and (b) invoking a tenuous comparison among photographs, and maps, and charts. Concluding that a photograph was a writing in such a manner "deform[ed] the original constitutional reference to literary works." Burrow-Giles Court did not stop to consider the interpretive difficulties of ensuring that the modern-day dilemma that it faced-deciding whether a photograph was a copyrightable writing-actually matched the decision made by the First Congress. As a result, it made its decision on highly questionable grounds, with lasting consequences for the field of copyright.

The Court's acceptance of a photograph as a protected writing essentially gave Congress almost free reign to expand the definition of copyright to the point where vessel hulls, video games, and vacuum cleaners can all be protected "writings."227 Almost a century after Burrow-Giles, the Supreme Court upheld the expanded definition of "writings" in Goldstein $v$. California, finding that sound recordings could be protected under copyright law. ${ }^{228}$ The Court conceded that the word has:

not been construed in [its] narrow literal sense but, rather, with the reach necessary to reflect the broad scope of constitutional principles. ... [A]lthough the word "writings" might be limited to script or printed material, it may be interpreted to include any physical rendering of the fruits of creative intellectual or aesthetic labor. ${ }^{229}$

Under this remarkably broad definition, almost any human endeavor could qualify as a writing for copyright purposes. The Court traced this broad reading of the word "writings" back to Burrow-Giles and its questionable use of the First Congress canon.

A rethinking of the constitutional basis of copyright need not undermine all protections afforded to non-writings such as Balinese dancer statuettes or photographs, as some have asserted. ${ }^{230}$ Congress could, for example, provide similar coverage under a sui generis protection scheme,

226. GaINES, supra note 211 , at 54 n.32.

227. See 17 U.S.C. $\S \S 1301-32$ (2001) (codifying the Vessel Hull Design Protection Act); U.S. Copyright Office, Games, http://www.copyright.gov/fls/fl108.html (last visited February 15, 2006). A vacuum cleaner could qualify for copyright as a pictoral, graphical, or sculptural work. See 17 U.S.C. $\S 102(a)(5)(2001)$.

228. 412 U.S. 546 (1973).

229. Id. at 561 .

230. See Copyright, supra note 218, at 1263-64. 
using its Commerce Clause powers. ${ }^{231}$ As a result, a statutory change from copyright to sui generis protection may have little practical consequence. But the inelegant use of the First Congress canon in Burrow-Giles unmoored modern copyright from its constitutional foundations, rendering the word "writing" in the copyright clause of the Constitution largely irrelevant. The Burrow-Giles Court invoked the First Congress canon with insufficient caution, making a tenuous comparison between mechanical photographs and constitutional "writings" that has likely made modern copyright protection unrecognizable to the Framers who adopted it in the Constitution.

\section{The Negative Use of the Canon: Justice Thomas and Utah v. Evans}

Assuming that the First Congress canon can be used to clarify what powers the Constitution granted to Congress, can it also be used to demonstrate the limits of those powers? In Utah v. Evans, two Justices argued that it could. ${ }^{232}$ The case involved the use of statistical methods to estimate the current U.S. population. The U.S. Constitution requires an "actual Enumeration" every decade, and Congress has barred the U.S. Census Bureau from using "sampling" techniques to apportion seats in the House of Representatives. ${ }^{233}$ The Bureau relied instead on a statistical method called "hot-deck imputation," which attempts to fill in gaps in the actual collected data. ${ }^{234}$ The State of Utah, which lost a seat in the House as a result, sued to prevent the Bureau from using this method. A fractured Court upheld the practice, since filling in the gaps (imputation) was not the same as projecting overall results from a smaller slice of the population (sampling). ${ }^{235}$

Justices Clarence Thomas and Anthony Kennedy argued in dissent that the actions of the First Congress should have helped decide the question. Its regulations for the first census gave Justice Thomas "additional evidence that the Framers meant what they said in adopting the words 'actual Enumeration." "236 These required that census takers actually count the people, with no mention of "the use of sampling or any other statistical technique or method of estimation." ${ }^{237}$ Justice Thomas concluded from his

231. Whether or not Congress has this power would have to be decided by the courts. Copyright scholar Pamela Samuelson has argued that "[i]f the [Supreme] Court believed that Congress was invoking the Commerce Clause in order to circumvent constitutional limitations on its powers under the Intellectual Property Clause, the Court might be disinclined to permit this subterfuge." Samuelson, supra note 8 , at 566 .

232. 536 U.S. 452, 488 (2002) (Thomas, J., dissenting).

233. See U.S. ConST. art. I, § 2, cl. 3 ; 13 U.S.C. $\$ 195$ (2001).

234. Evans, 536 U.S. at 457.

235. Id. at 467 .

236. Id. at 503.

237. Id.; see also Act of Mar. 1, 1790, $§ 1$. 
historical review that "[n]o other method of counting appears to have been permissible." 238 "Hot-deck imputation" in the 2000 census stretched the words "actual Enumeration" beyond their limits and was thereby unconstitutional.

Justice Thomas' negative use of the canon is particularly troubling. He implicitly argues that if the First Congress did not legislate in a particular way, then subsequent Congresses may not either. If the First Congress chose to authorize an actual count without statistical estimations, then this must be the only method permitted by the Constitution. He supplements this understanding with a historical sketch demonstrating, at least to his satisfaction, that the Framers were concerned less with the accuracy of the count than with the political manipulation that might result from statistical estimates. ${ }^{239}$ Justice Thomas concluded that since the Framers' primary goal was to shield the census from partisan politics, the exact precision of the count was a lesser priority, so statistical methods such as "hot-deck imputation" could therefore not be justified.

His argument assumes that the Constitution envisions only one allowable means of determining the population, and the First Congress necessarily followed that method, imbued as it was with the wisdom of the Framers. This, however, attaches heavy weight to the simple words "actual Enumeration." Although this phrase, on its face, could mean many different things, Justice Thomas attempts to show it can only mean an actual physical count of every person in the United States. ${ }^{240}$ The argument is at its core a shallow one. The Constitution must mean an actual physical count with no estimation. Why? Because the First Congress did it that way, and that estimable body certainly could not have acted unconstitutionally. The negative use of the canon, showing that the failure of the First Congress to act in a certain way demonstrated that it could not constitutionally act in that way, is particularly weak. It ignores the role of the Constitution as a framework of government, with the specific details to be hashed out among the three coordinate branches.

III

\section{MEASURING ACQUIESCENCE}

Even if the Supreme Court can successfully interpret the actions of the First Congress and correctly apply these to modern-day constitutional questions, it must then determine whether other branches of government have acquiesced in the First Congress' constitutional interpretation. According to Justice Story in Prigg v. Pennsylvania, "if the question were one of doubtful construction, such long acquiescence in it, such

238. Evans, 536 U.S. at 504.

239. Id. at 506 .

240. See id. at 491-96. 
contemporaneous expositions of it, and such extensive and uniform recognition of its validity, would in our judgment entitle the question to be considered at rest." 241 Justice Lucius Lamar later explained the theory behind relying on acquiescence: "[G]overnment is a practical affair intended for practical men. Both officers, law-makers and citizens naturally adjust themselves to any long-continued action of the Executive Department- - on the presumption that unauthorized acts would not have been allowed to be so often repeated as to crystallize into a regular practice. $" 242$

The task of locating acquiescence appears, at first glance, to be quite simple: an unbroken practice is an unbroken practice. But what exactly constitutes acquiescence, and how long must it last for it to become determinative? Furthermore, coordinate branches of government may have legitimate reasons for withholding criticism of legislative decisions that may not indicate acquiescence at all. Just as the Supreme Court has failed to fully justify the interpretive weight it places on the acts of the First Congress, it has similarly not grappled with the question of acquiescence.

\section{A. The Duration of Acquiescence}

The Supreme Court has never clearly articulated how long a coordinate branch of government must defer to the legislature in order for its inaction to constitute acquiescence. A classic 1896 text on constitutional and statutory interpretation explained that "English cases speak of a period of two or three hundred years. In this country, where no such statutory age is as yet possible, a very much shorter period of time would probably suffice to justify the courts in considering the usage." 243 Nevertheless, "the principle of 'contemporenea expositio' is not applicable to laws recently passed. And the degree of force which should attach to the argument from usage will increase with the age of the usage." 244 The text conceded in the end that "in the nature of things it cannot be very definitely settled" how long acquiescence must last. ${ }^{245}$

Although the length of acquiescence necessary under the First Congress canon is clearly not capable of quantitative determination, the Supreme Court has at times skirted the boundaries of what can be considered proper acquiescence. In Stuart $v$. Laird, for example, the Court found the length of time between the I789 Judiciary Act and the 1801 Judiciary Act, a mere twelve years, to be sufficient to establish acquiescence. ${ }^{246}$ This is a far cry from the "two or three hundred years" necessary under British

\footnotetext{
241. 41 U.S. 539, 621 (1842).

242. United States v. Midwest Oil Co., 236 U.S. 459, 472-73 (1915).

243. Henry Campbell Black, Handbook on the Construction and interpretation of THE LAWS 217 (1896).

244. Id.

245. Id.

246. See 5 U.S. 299 (1803).
} 
law to establish acquiescence. ${ }^{247}$ Indeed, Stuart held that acquiescence must last only "for a period of several years."248

\section{B. The Definition of Acquiescence}

With such a low threshold for the time necessary to establish acquiescence, the Court's historical examination of whether or not other branches resisted the First Congress' actions should be more rigorous. However, the Court has never set standards for what constitutes acquiescence, nor has it seriously analyzed how to determine whether resistance has developed.

In McCulloch v. Maryland, for example, the Court held that the period of acquiescence need not be continuous. ${ }^{249}$ That case decided the constitutionality of the bank of the United States, which the Congress first created in 1791. The bank debate pitted Framers against each other, with Alexander Hamilton proposing the bank as the Secretary of the Treasury and James Madison leading the opposition in the House of Representatives. ${ }^{250}$ Hamilton argued that the Necessary and Proper Clause in Article 1 of the Constitution gave Congress the power to establish a bank, while Madison retorted that such a broad interpretation of that clause "would render nugatory the enumeration of particular powers." Congress authorized the bank only after heated debate over its constitutionality. ${ }^{252}$

The statutory authorization for the bank, however, expired in $1811 .^{253}$ As Secretary of State, Thomas Jefferson had vigorously opposed the creation of the bank and called for President Washington to veto it. Yet when Jefferson himself became President in 1801, he chose to wait until the bank expired rather than to challenge it directly. ${ }^{254}$ Throughout its life, the bank was politically unpopular in a nation where the Federalists had lost all political power, and states often opposed the bank because it competed with

\footnotetext{
247. BLACK, supra note 243, at 217.

248. Stuart, 5 U.S. at 299.

249. 17 U.S. 316 (1819).

250. See Chernow, supra note 141 , at 344,349 .

251. For Hamilton's arguments, see Letter from Alexander Hamilton to George Washington (Feb. 21,1791 ), in 8 The Papers of Alexander Hamilton 58 ( 1987). For Hamilton's arguments, see 2 ANNALS OF CONGRess, supra note 81, at 1946. Ironically, Madison's arguments against the bank contradicted those he made concerning the Necessary and Proper Clause in The Federalist four years before, in which he wrote: "No axiom is more clearly established in law or in reason than wherever the end is required, the means are authorized; wherever a general power to do a thing is given, every particular power for doing it is included." THE Federalist No. 44 (James Madison).

252. 1 Cong. ch. 10; 1 Stat. 191 (1791).

253. Id. $\S 3$.

254. See Opinion of the Constitutionality of the Bill for Establishing a National Bank, in 19 THE Papers of Thomas JefFerson 275 (Julian P. Boyd ed., 1974). Jefferson, however, continued to believe that the bank was unconstitutional. See Bray Hammond, Banks and Politics in America 205, 207 (1957).
} 
their own institutions. ${ }^{255}$ Congress, therefore, refused to reauthorize the bank in 1811. However, the War of 1812 and the promiscuity of state banks in issuing bank paper devastated the country's finances, and demand grew for another national bank. ${ }^{256}$ President Madison, who had campaigned against the first bank in the House, vetoed the second bank bill in 1815 on practical grounds, although he did now support the idea of a second bank. ${ }^{257}$ Congress finally passed a bank bill acceptable to Madison the next year. Even so, many states vigorously opposed the bank, and seven states passed anti-bank statutes, one of which found its way to the Supreme Court in $\mathrm{McC}$ ulloch v. Maryland. ${ }^{258}$

This brief history of the bank illustrates that significant opposition existed not only at its inception, but throughout its history. Jeffersonian Republicans detested the very notion of the bank and never formally conceded its constitutionality. When the bank expired in 1811, Congress refused to reauthorize it until war and financial crises forced it to capitulate. The bank's five-year absence, however, did not appear to influence the Court in $\mathrm{McC}$ Culloch:

The original act was permitted to expire; but a short experience of the embarrassments to which the refusal to revive it exposed the government, convinced those who were most prejudiced against the measure of its necessity, and induced the passage of the present law. It would require no ordinary share of imtrepidity to assert that a measure adopted under these circumstances was a bold and plain usurpation, to which the constitution gave no countenance..$^{259}$

The Court did not indicate that the numerous opponents to the bank, or even those who acceded to its necessity, had ever conceded its constitutionality or accepted the Necessary and Proper Clause theory of constitutionality. Instead, Justice Marshall simply declared, in an example of "history ... by judicial fiat," that the opposition had acquiesced, thereby fixing the meaning of the Constitution. ${ }^{260}$

Political actors, however, have various reasons for acquiescence that may have nothing to do with the constitutionality of a measure. President

255. See WARREN, supra note 40 , at 504 .

256. Id. at 505

257. See Veto Message (Jan. 30, 1815), in 8 ThE WRITINGS of JAMEs MADison, supra note 80, at 327. Madison, however, indicated that his veto was based on practical grounds. His personal views on the constitutionality of the measure were precluded "by repeated recognitions under varied circumstances of the validity of such an institution in acts of the legislative, executive, and judicial branches of the Government, accompanied by indications, in different modes, of a concurrence of the general will of the nation...."Id.

258. The states passing anti-Bank legislation included Georgia, 11linois, Kentucky, Maryland, North Carolina, Ohio, and Tennessee. See WARREN, supra note 40, at 505.

259. McCulloch v. Maryland, 17 U.S. 316, 402 (1819).

260. Kelly, supra note 12, at 122. Professor Kelly singled out McCulloch v. Maryland as an example of this practice. See id. at 123 n. 18. 
Jefferson, for example, decided to let the bank live out its statutory life for political reasons without ever conceding its constitutionality. ${ }^{261}$

Other actors may acquiesce simply because they failed to consider the constitutional implications of a measure. Constitutional arguments can obviously be highly complex and counterintuitive, so the constitutional implications of a congressional act may not initially be apparent. The constitutionality of circuit riding in Stuart $v$. Laird provides an excellent example of this. The Constitution does not explicitly prevent Supreme Court Justices from ruling on disputes at the circuit court level, but its practice may violate the Presidential Appointment Clause and the limitations on the grant of original jurisdiction to the Supreme Court. ${ }^{262}$ Justice Samuel Chase, although he had ridden circuit since his appointment in 1796, confessed in 1802 that he had never given serious thought to the constitutionality of the practice.

[T] he Judges have held Circuit Courts ever since the formation of the Federal Government, until the late Judiciary Law. The fact is so. 1 can truly say that I never considered the question. 1 acted as a Circuit Judge, because my predecessors had done so before me, without any enquiry into the subject $\ldots .^{263}$

John Marshall, similarly, confessed to having so much respect for the members of the First Congress, that he simply never considered whether one of their acts might violate the Constitution. ${ }^{264}$ Because of this deference, he never investigated the issue until the Repeal Act of 1802 placed the issue squarely before the justices. "The result of this investigation," he wrote to Justice Paterson, "has been an opinion which I cannot conquer that the constitution requires distinct appointment $\&$ commissions for the Judges of the inferior courts from those of the supreme court."265

Other justices offered different reasons for their apparent acquiescence. John Jay, in his letter to President John Adams declining a second appointment as Chief Justice because of the rigors of circuit riding, indicated that he had expected the Judiciary Act of 1789 to "be amended[] as the public mind became more composed and better informed."266 These expectations, however, "have not been realized [and] the [e]fforts repeatedly made to place the judicial [d]epartment on a proper [f]ooting

261. See Hammond, supra note 254 , at 207.

262. See U.S. ConsT. art. II, § 2; art. III, § 2.

263. Letter from Samuel Chase to John Marshall (Apr. 24, 1802), in Marshall Papers, supra note 47 , at 115 .

264. Letter from John Marshall to William Paterson (Apr. 19, 1802), in Marshall PAPERs, supra note 47 , at 108 .

265. Id.

266. Letter from John Jay to John Adams (Jan. 2, 1801), in 2 DHSC, supra note 43, at I46. 
have proved fruitless." ${ }^{267}$ Those efforts included a letter from the Justices, perhaps never sent, explaining:

That when the present Judicial arrangements took place, it appeared to be a general and well founded opinion, that the Act then passed was to be considered rather as introducing a temporary expedient, than a permanent System, and that it would be revised as soon as a period of greater leisure should arrive. ... The ensuing Sessions of Congress were so occupied by other affairs of great and pressing importance, that the Judges thought it improper to interrupt the attention of Congress by any application on the subject. ${ }^{268}$

Jay also lobbied individual members of Congress, including his friend Rufus King, senator from New York. "It has happened in more than one instance,' Jay wrote to King, 'that questions in the Circuit Court decided by one set of Judges in the affirmative had afterwards in the same Court been decided by others in the negative .... [T] his evil has no remedy [except] . . by confining the Judges to their proper place, viz. the Supreme Court.",269

The Justices' apparent acquiescence was nothing of the sort. It was merely a respectful patience while the Congress sorted through the mistakes it made during the early years of the republic. The fact that Congress never did correct the apparent mistake of circuit riding vexed the Justices, but they failed to overturn the practice when they had the chance in Stuart v. Laird. Only then did the Court officially acquiesce.

This deference that the Justices showed toward Congress was by no means unique in the early republic. The centrality of Congress in the new Constitution led other political actors to demonstrate frequent and often uncritical respect for the legislative branch. ${ }^{270}$ President Washington regularly deferred to the wisdom of Congress and vetoed bills only on the rare occasions when he believed a measure to be unconstitutional. ${ }^{271} \mathrm{He}$ did not veto a single bill during the First Congress and vetoed only two measures

267. Id. at $146-47$.

268. Letter from the Justiccs of the Supreme Court to the Congress of the United States (Aug. 9, 1792), in 2 DHSC, supra note 43, at 289.

269. WARREN, supra note 40 , at 87 .

270. For example, Thomas Jefferson, scrving as President Washington's Secretary of State in 1791, wrote a persuasive letter to the president urging him to veto the Bank of the United States bill. The letter expressed Jefferson's profound beliefs that the bank violated the Constitution. However, even he qualified his plea to Washington by indicating that unlcss the President was:

[T]olerably clear that it is unauthorised by the constitution ... a just respect for the wisdom of the legislature would naturally decide the balance in favour of their opinion. It is chiefly for cases where they are clearly misled by error, ambition, or interest, that the constitution has placed a check in the negative of the President.

19 The Papers of Thomas JefFerson, supra note 254, at 280.

271. James MacGregor Burns \& Susan Dunn, George Washington 66 (2004). 
during his entire presidency. ${ }^{272}$ Nor did he propose specific legislation for Congress to consider out of "“[m]otives of delicacy." "273 At most, Washington forwarded general ideas to Congress but, he said, "it rests with them to decide what measures ought to be adopted for promoting the suecess of the great objects, which I have recommended to their attention."'274 Taking the constitutional dictate of "advice and consent" seriously, President Washington even formally solicited the advice of Senators on upcoming Indian treaties during a personal visit to the Senate. ${ }^{275}$ Washington sought to keep himself above the hard-scrabble politics that developed around him, seeing himself primarily as a symbol who could unite a fractured America. ${ }^{276} \mathrm{He}$ was, in short, not one who would challenge the validity of congressional enactments.

His attitude toward the Judiciary Act of $I 789$ further demonstrates his deference to Congress. Washington believed a strong judiciary, led by the Supreme Court, would be the "Key-Stone of our political fabric" that would cement the nation together. ${ }^{277}$ The final judiciary bill, however, was the result of political compromises that reflected the general fear in the country of a centralized federal judiciary ${ }^{278}$ The bruising campaign to ratify the Constitution over the previous two years had divided the nation over the powers of the federal government. The federal district and circuit courts were a particularly sensitive political issue because they would be the most visible face of federal power in many states and communities far from the capitol in Philadelphia. ${ }^{279}$ As a result, the judiciary bill was purposely vague on the powers of the new judiciary in order to avoid alarming proponents of state sovereignty. ${ }^{280}$ Although Washington disagreed with much of the bill, he deferred to the power of Congress and did not challenge it, despite the fact that it contained at least one unconstitutional provision, which Marbury v. Madison later correeted. ${ }^{281}$

If political realities could lead both the Supreme Court and the President to defer to the will of Congress in the early republic, then the argument that such acquiescence fixed the meaning of the Constitution loses much of its force. This is particularly true if the period of acquiescence can

\footnotetext{
272. Id.

273. Id. at 77 .

274. Id.

275. See Stanley Elkins \& Eric McKitrick, The Age of Federalism 55-58 (1993). The appearance was so miserable for Washington, with Senators bitterly squabbling over procedural issues, that Washington stormed out. Although Washington returned one more time to consult with the Senate over a treaty, it was his last such appearance. Id. at 56.

276. Joseph J. Ellis, His Excellency: George Washington 186, 194 (2004).

277. See id. at 200.

278. Id.

279. See WARREN, supra note 40 , at 58,63 .

280. ELLIS, supra note 276, at 200.

281. Id.
} 
be as short as that indicated in Stuart v. Laird. Even if private third parties challenged the actions of the First Congress, as John Laird did in 1802, the Supreme Cnurt might be likely to defer to the will of Congress.

Furthermore, many congressional acts did not receive the level of judicial scrutiny that similar measures would receive today, in part because constituencies did not yet exist to challenge them. For example, Eric Eldred challenged the passage of the Copyright Term Extension Act in 1998 because it deprived his business of its ability to publish works on the Internet that regularly entered the public domain. ${ }^{282}$ However, when Congress extended copyright protection to books, maps, and charts in 1790 , it is likely that no publisher was damaged by the Act, since no industry at that time capitalized on the niche market of works entering the public domain. ${ }^{283}$ Contemporary American publishers frequently pirated works enjoying copyright protection in England, as copyright law had yet to effectively address international infringement of intellectual property. ${ }^{284}$ For example, the 1790 Copyright Act protected only the interests of American authors, but did not extend its reach to works created by British nationals. ${ }^{285}$ American printers thrived on pirating foreign works, and until the Civil War, half of the bestsellers in the United States were pirated from foreign works. ${ }^{286}$ As a result, most books published in the United States during the early years of the republic were in fact copies of editions originally published in London, and a significant domestic book industry was slow to develop. ${ }^{287}$ Because so much of their business depended on flouting copyright law, it was unlikely that any early American publisher would have chosen to raise a public challenge to the 1790 Copyright Act. Such silence is therefore more a sign of business strategy than acquiescence in the constitutionality of the law, and it tells us nothing about whether the 1790 copyright act was in fact constitutional. This stands in marked contrast to Eldred's situation two centuries later.

The executive and judicial branches of the new government in 1789 were thus rcluctant to challenge the power of the First Congress over a number of constitutional issues. Nor could private parties be expected to take up the burden, in part because parties with sufficient standing may not have existed and in part because they may have met with a judiciary deferential to the views of Congress. Such complexities undermine the heavy

282. For Eldred's business, see Eldritch Press, http://www.eldritchpress.org (last visited March 6, 2006).

283. See Thomas Bender \& David Sampliner, Poets, Pirates, and the Creation of American Literature, 29 NYU J. INT'L L. \& Pol. 255, 257-58 (1996-1997).

284. See Lehmann-Haupt, supra note 216, at 93-94; See also Peter K. Yu, The Copyright Divide, 25 Cardozo L. Rev. 331, 337 (2003).

285. Id.

286. Yu, supra note 284 , at $341-42$.

287. Id. at 337-38. 
reliance that the Supreme Court has placed on acquiescence in its various invocations of the First Congress canon.

\section{Conclusion}

The First Congress canon is not entirely without merit. If judges decide that contemporaneous practices can inform constitutional interpretation, then the actions of the First Congress must be considered as one piece of evidence. But such evidence cannot be solely dispositive. The inherent difficulties of interpreting the actions of the early legislature and of then applying these lessons to modern-day constitutional quandaries counsel a degree of judicial caution. Courts in general lack the institutional capacity to explore the complexities of the past, concerned as they are with the vexing issues of the present. As constitutional historian Jack Rakove has argued:

$[\mathrm{H}]$ istorians have little stake in ascertaining the original meaning of a clause for its own sake, or in attempting to freeze or still its true, unadulterated meaning at some pristine moment of constitutional understanding. They can rest content with-even revel in-the ambiguities of the evidentiary record, recognizing that behind the textual brevity of any clause there once law a spectrum of complex views and different shadings of opinion. ${ }^{288}$

Judges do not have this luxury, but must speedily make decisions by divining the "true" meaning of a constitutional clause. As a result, courts will to some degree always practice a version of "law-office history" or "history... by judicial fiat." 289 At a minimum, however, the Supreme Court should grapple with the theoretical issues that the canon presents. If it continues to invoke the canon, it must provide a fuller explanation of why the actions of the First Congress provide a reliable source of evidence to guide the resolution of difficult constitutional issues two centuries after the fact. Finally, if the Court insists on employing the First Congress canon, it must do so more modestly, using the historical actions of the first legislature only to provide some insight into modern-day dilemmas, rather than dictating outcomes. The decisions of the First Congress should never be dispositive to constitutional interpretation, but should merely be consulted for guidance. Only in this way can the Court's use of the First Congress canon be reconciled with the inherent difficulties of historical interpretation.

288. RaKove, supra note 133, at 9-10.

289. Kelly, supra note 12, at 122. 